
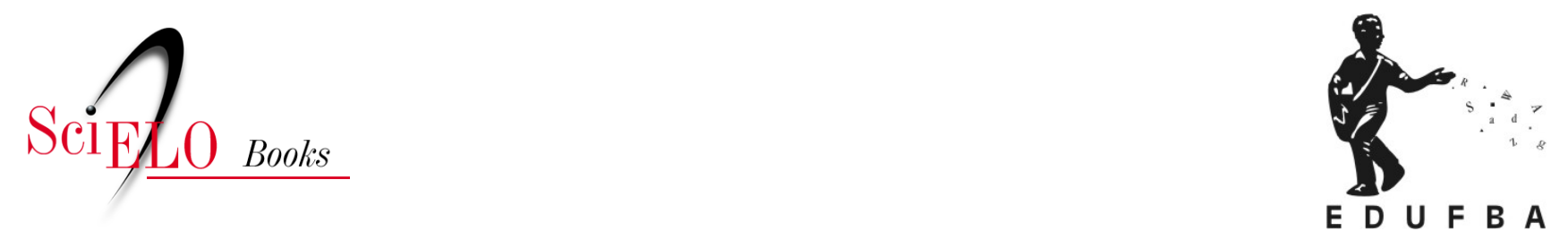

\title{
"Seus viciados pertencem à última e mais baixa escala social" histórias de gatunos, trabalhadores "maconheiros" e outros desv(ar)ios inebriantes
}

\author{
Jorge Emanuel Luz de Souza
}

\section{SciELO Books / SciELO Livros / SciELO Libros}

SOUZA, J.E.L.S. "Seus viciados pertencem à última e mais baixa escala social": histórias de gatunos, trabalhadores "maconheiros" e outros desv(ar)ios inebriantes. In: Sonhos da diamba, controles do cotidiano: uma história da criminalização da maconha no Brasil republicano [online]. Salvador: EDUFBA: CETAD/UFBA, 2015, pp. 91-160. Drogas: clínica e cultura collection. ISBN: 978-85-232-20235. https://doi.org/10.7476/9788523220235.0005.

All the contents of this work, except where otherwise noted, is licensed under a Creative Commons Attribution 4.0 International license.

Todo o conteúdo deste trabalho, exceto quando houver ressalva, é publicado sob a licença Creative Commons Atribição $\underline{4.0}$. 


\section{"SEUS VICIADOS PERTENCEM À ÚLTIMA E MAIS BAIXA ESCALA SOCIAL": HISTÓRIAS DE GATUNOS, TRABALHADORES "MACONHEIROS" E OUTROS DESV(AR)IOS INEBRIANTES}

Figura 1 - Dados sobre usuários de maconha na Bahia

J. A. S. - pardo, 30 anos, solteiro, alfaiate, nada de anormal.

V. A. F. - branco, 19 anos, solteiro, carpinteiro, nada de anormal.

A. L. L. - prêto, 21 anos, solteiro, carregador, apresenta-se alegre,

A. A. S. - branco, 35 anos, solteiro, carregador, embriaguez canábica.

M. S. A. - pardo, 20 anos, solteiro, grande fome e alegria.

E. T. - pardo, 29 anos, soldado da Fôrça Pública, ora alegria e ora depressão.

A. P. S. - pardo, 19 anos, solteiro, engraxate, muita fome,

M. J. S. - prêto, 25 anos, solteiro, carregador, nada de anormal.

J. B. S. - prêto, 16 anos, solteiro, vendedor ambulante, fome e vertigens.

G. B. S. - prêto, 21 anos, solteiro, paqueteiro, embriaguez canábica.

J. M. S. - preto, 37 anos, solteiro, sapateiro, alegria, bem-estar, euforia canábica.

D. S. L. - prêto, 20 anos, solteiro, peixeiro, estado de embriaguez.

F. S. L. - prêto, 17 anos, solteiro, engraxate, animação e alegria.

Fonte: Parreiras (1958, p. 257).

As informações acima são parte de dados apresentados por Décio Parreiras (1958), membro da Academia Nacional de Medicina e da Comissão Nacional de Fiscalização de Entorpecentes, nos fins da década de 1940 sobre usuários de maconha na Bahia, num extenso relatório sobre as várias partes do país publicado sob o título "Canabismo ou Maconhismo (Estudos Brasileiros)". Foram fornecidas por Antônio Simões, João Ignácio de Mendonça e Antônio Crisippo de Aguiar, membros da Comissão Estadual de Fiscalização de Entorpecentes numas das visitas de inspeção realizadas pela CNFE à região Nordeste. 
Como visto, os referidos órgãos eram os responsáveis pelo combate às "toxicomanias" em nível nacional e estadual respectivamente, integrando o amplo conjunto de políticas públicas sobre o tema levadas a cabo durante o primeiro governo Vargas e que teve a maconha como foco privilegiado.

Dentre as profissões de 61 "maconheiros" presos nas penitenciárias da capital em 1949 listados no relatório de Parreiras, 50 são definidas como: colchoeiro, jornaleiro, taifeiro, barbeiro, vendedor ambulante, engraxate, aguadeiro, carregador, funileiro, motorista, coveiro, marítimo, mecânico, peixeiro além de tecelões, carpinteiros, pedreiros, alfaiates, açougueiros e sapateiros. Todas são ocupações das classes subalternas. Pode-se encontrar também boa parte dessas categorias funcionais na linha de frente das manifestações e dos conflitos sociais contra a carestia de vida ao longo de toda a Bahia republicana até então. (SANTOS, 2001)

Essa característica merece, pelo visto, mais atenção. Em verdade, a acusação de "maconheiro" no Brasil havia algum tempo era aplicada a um vasto conjunto de personagens sociais identificadas entre as "populações nortistas pobres". (MENDONÇA, 1958, p. 99) Seus “afeiçoados" seriam, sobretudo, naturais da Bahia, Sergipe, Alagoas, Pernambuco, Pará e Maranhão e, predominantemente, "negros e pardos"; poderiam ser os "canoeiros, pescadores" e todos os tipos de embarcadiços, acusados de serem os maiores responsáveis pela propagação do vício; poderiam ser os sertanejos, bem como os adeptos dos catimbós, xangôs e candomblés; estariam também entre o vasto e heterogêneo conjunto dos trabalhadores urbanos; e sem dúvidas a maconha seria encontrada em posse de "gatunos", malandros, boêmios, "larápios", "mundanas" e "decaídas". (CURIOSA, 1958, p. 7) 
Esse mundo inquieto das classes subalternas foi apontado por autoridades e especialistas por mais de meio século como morada preferida da maconha no Brasil. O discurso condenatório da maconha será uníssono, até a primeira metade da década de 1960, em considerar que "[...] seus viciados geralmente pertencem à última e mais baixa escala social, são mesmo analfabetos e sem cultura". (ROCHA, 1958) Mas por quê? Por que só os da "mais baixa escala social"? Só os pobres consumiam maconha?

A afirmação feita pelo dr. Irabussú Rocha, diretor do Serviço Nacional de Educação Sanitária, no prefácio à segunda edição de "Maconha - Coletânea de trabalhos brasileiros", poderia não corresponder exatamente à realidade de usos da maconha na sociedade, mas dá indícios dos conflitos sociais do período quando a questão era o uso de drogas. É esse, precisamente, o tema deste capítulo. Deve-se contextualizar a ideia acima, tomada de forma generalizada pelos especialistas do proibicionismo da maconha, para evidenciar que havia questões específicas da vida cotidiana dos subalternos que atraía a atenção das autoridades responsáveis pela campanha e às quais a acusação de "maconheiro" era aplicada.

Assim como em todo o país, mas com suas especificidades, as formas de ganhar a vida da classe trabalhadora soteropolitana, os lugares que viviam e frequentavam, suas crenças, práticas de cura e estados de consciência, seus divertimentos, sua mobilidade no espaço e as relações que estabeleciam há muito eram um terreno de conflito entre estes sujeitos e o poder público. A compreensão da sua dinâmica durante as décadas centrais do século XX permitirá elucidar os fatores políticos mais amplos, difusos no contexto histórico, da repetida associação entre subalternos e maconha no Brasil. 
Sonhos da diamba

Desde o início da década de 1950 até meados da seguinte os jornais de Salvador montaram uma imagem negativa do usuário de maconha com base nos termos do discurso proibicionista, privilegiando exclusivamente aqueles das classes subalternas. Portanto, se tentará surpreender, principalmente, nas matérias que tratavam do assunto nesse decênio, elementos que ajudem a compreender por que apenas os pobres da cidade eram acusados de "maconheiros".

A vida dessa volumosa parcela da população soteropolitana nunca foi das mais fáceis. Um desses grupos de trabalhadores urbanos foi especialmente vigiado e associado à maconha: o do comércio popular, sobretudo ambulantes, camelôs e feirantes. Longe de ser uma invenção da República, tanto no período colonial quanto no Império, várias foram as iniciativas das autoridades públicas nesse sentido. (REIS, 1993) No século passado, desde a década de 1920 que o poder público da cidade recriava mecanismos de fiscalização e disciplinarização para quem exercesse o comércio popular na rua, a exemplo do Ato n. 127 de 5 de novembro de 1920, o Código de Posturas Municipais. (PAIM, 2005)

Fossem os que perambulavam de porta em porta, fossem os que se estabeleciam nas muitas feiras livres da capital, que no mais das vezes poderiam ser as mesmas pessoas ou da mesma família, a atividade por eles desenvolvida sempre incomodou membros das elites econômicas da cidade, que a consideravam como uma herança arcaica, um símbolo de atraso e decadência. O comércio popular nas ruas de Salvador expunha os desniveis sociais e obrigava-os a transitar, compartilhar do mesmo espaço, o que não agradava muito as "boas famílias". (LEITE, 1996)

Um desses ambulantes, às nove horas da manhã do dia 4 de janeiro de 1953, tentou burlar a vigilância da Penitenciária do Estado. O caso foi noticiado por A Tarde: 
Um caso surpreendente, por que denuncia meios clandestinos de incentivação do uso de opiáceas na Penitenciária do Estado, senão a própria existência de uma quadrilha ou organização, que faz chegar às mãos dos presidiários o entorpecente, chegou ao conhecimento da Delegacia Auxiliar, na forma de um flagrante delito, centralizando a figura do vendedor ambulante Severino Correia Trindade $[. .$.$] .$

O vendedor ambulante apresentou à guarda do presídio, pedindo para visitar um preso qualquer. No momento em que era revistado, descobriram em seus bolsos um pacote pequeno, contendo folhas, que ele não explicou quais eram. Não obstante, o pacote foi apreendido e identificado, por uma pessoa da administração, como contendo maconha. Preso, o vendedor foi levado à Delegacia Auxiliar $[\ldots]$.

[...] Ademais, acresce a circunstância de que o vendedor pode ser enquadrado como traficante, pois, estando sem dinheiro, é provável que tivesse ido à Penitenciária vender aos presidiários o entorpecente. (LEVAVA, 1953, p. 5 , grifo nosso)

A matéria coloca o vendedor ambulante Severino Correia no centro de uma quadrilha que fornecia maconha aos detentos da penitenciária. Adverte também que o delito cometido era grave o suficiente para enquadrá-lo como traficante e, por fim, sugere que as dificuldades financeiras teriam o impelido ao tráfico da erva. Apresenta um discurso condenatório, considerando a maconha uma opiácea, caracterização não desprovida de precedente, pois a literatura médica havia relacionado os efeitos da maconha aos do ópio havia tempo.

Demonstra também conhecimento em relação à legislação que regulava a questão, considerando a posse elemento caracterizador do crime. E como o Decreto-Lei n. 891 de 1938 equiparava diversas condutas no seu artigo 33, tais como facilitar o uso, vender, dar, ministrar, guardar, transportar e consumir substâncias psicoativas, habilmente transforma essa 
posse em tráfico. Isso significava, caso condenado, um a cinco anos de prisão e multa de mil a cinco mil cruzeiros. A matéria vai buscar, então, no contexto social da época a validade para a acusação ao frisar a complicada situação econômica do vendedor ambulante, pois a carestia de vida, que atravessou toda a primeira metade do século, ainda se manifestava nesse decênio em Salvador. (FREITAS, 1985)

Essa era a situação de Severino e de um grande número de ambulantes que assim como ele trabalhavam nas ruas da cidade e aprendiam a enfrentar, burlar e negociar com os prepostos da fiscalização municipal em seu dia a dia para que não confiscassem suas mercadorias caso sua atividade estivesse em desacordo com o Código de Posturas Municipais. Sendo assim, sem apresentar a sua versão do ocorrido, se a maconha que tinha em seus bolsos era para uso pessoal ou para vender, o noticiário coloca sob suspeita não apenas Severino, mas os muitos ambulantes que também "estavam sem dinheiro" num contexto de carestia. Essa seria, segundo a matéria, a motivação para o crime e, como havia muita gente nessa condição, tornava a todos potenciais traficantes.

Oito anos depois do ambulante Severino, em maio de 1961, o camelô Claudionor de Jesus, "conhecido pelo vulgo de 'Nouquinha", foi acusado pelo policial Edgar Xavier de furtar a carteira de um estudante na Baixa dos Sapateiros "em frente à loja Alves Irmãos", por isso preso e levado para a Delegacia de Furtos e Roubos, uma das especializadas da capital. Depois de descrever a captura do acusado a matéria apresenta seus "péssimos antecedentes" e mais um "agravante":

[...] Nessa oportunidade soube-se que 'Nouquinha', conta várias entradas na Polícia, como 'batedor' de carteiras, principalmente em bolsas e sacolas de senhoras. 
Ao ser revistado pelo detetive Mario de Carvalho, este encontrou no bolso do short do acusado um pequeno pacote de maconha enrolado em papel de cigarro [...]. (BATEU, 1961, p. 3)

A matéria parece não buscar diretamente uma explicação para o fato, limitando-se a narrar o que teria acontecido. Deixando a justificativa repousar na imagem suspeita que construíam para os sujeitos ligados ao comércio popular, como já foi visto, reforçam essa ideia: um camelô, reincidente, roubou uma carteira e ainda portava maconha. Tudo se encaixava na visão das autoridades policiais. Já se enviava "Nouquinha" rapidamente para a casa de detenção onde ficaria "à disposição da Justiça".

Na cidade, naqueles tempos, com ou sem maconha nos bolsos, ser camelô era viver numa guerra. Os "jornais 'associados' da Bahia" juntamente com a Federação do Comércio deflagraram "intensa campanha" contra a sua presença nas ruas:

A Prefeitura comunica que a partir de hoje os 'camelots' serão definitivamente afastados do centro da cidade, só podendo agir nas feiras públicas. A determinação que a Diretoria de Fiscalização tomou e o público espera que realmente venha agora a Prefeitura mostrar sua autoridade acabando com um problema dos mais para a cidade, uma vez que os 'camelots' estavam na realidade tomando conta da cidade, agindo de preferência no centro, obstruindo as principais vias públicas como, por exemplo, na Rua Chile, Avenida Sete de Setembro e rua dr. Seabra.

[...] Desnecessário que se diga que os 'camelots', exatamente por falta de repressão dos órgãos competentes, tomaram conta da cidade numa inflação revoltante ao comércio, pois a concorrência desleal na venda de mercadorias por preço inferior ao comércio comum era um fato [...]. (CAMELOTS, 1958, p. 3) 
Para pôr em prática a medida, a Prefeitura deveria atuar "em perfeita colaboração com a Polícia". A medida foi recebida com entusiasmo pela imprensa, que também manifestava a satisfação dos comerciantes da federação.

A leitura da matéria dá uma ideia do tamanho das forças que se uniam em oposição a esse grupo: prefeitura, imprensa, Federação do Comércio e polícia. Não tolerariam mais a forma como ocupavam o espaço público, ou melhor, não toleravam mais a sua presença nas vias mais importantes da cidade, naquelas consideradas as suas vitrines, seus símbolos de "modernidade" e "civilização". Afastando-os do centro e lhes autorizando trabalhar apenas nas feiras da cidade, o poder público tentava condicioná-los num único espaço, evitando a sua característica mobilidade e facilitando o controle. Nas feiras estariam fora das vistas da parcela abastada da cidade e dos visitantes, bem como sob o raio de ação da Lei n. 29 de 7 de dezembro de 1948, que atualizava o antigo dispositivo de 1920 e buscava disciplinar o comércio popular nos minimos detalhes. (PAIM, 2005)

A federação sentia-se vítima de "concorrência desleal", alegando que o "comércio ilegal" gerava prejuízos para o seu comércio, esse, "legal”. Tal questão pode ser traduzida de outra forma: o comércio formal cobrava caro e a população recorria ao informal, movimentado setor econômico da capital que também acabava por absorver grande parte da população economicamente ativa. ${ }^{12}$ (ASSIS, 1996)

Contudo, parece que esses agentes não se entenderam tão eficientemente e não foi tão fácil nem rápido se livrarem dos ambulantes e camelôs, pois no ano seguinte a imprensa ainda reclamava efetividade das medidas anunciadas pelo poder

12 Acredita-se que, apesar das significativas mudanças na estrutura econômica local, ocorridas no contexto seguinte, esse mercado informal não deixou de ter grande relevância na vida das classes trabalhadoras, mantendo boa parte das características que apresentava de longa data. 
público. (FEIRAS, 1959, p. 3) Em 1960 a situação não parecia ter mudado, pois a Associação Comercial teria como principal ponto de pauta de uma das suas reuniões do mês de março a situação dos "vendedores ambulantes", levando o diretor da Fiscalização Municipal, Dionízio Azevedo, a dar explicações sobre a morosidade do poder público na Rádio Sociedade da Bahia dias depois. (PAIM, 2005)

As acusações de abusos na ocupação do espaço público e de causarem prejuízos aos grandes comerciantes eram aplicadas a ladrões e maconheiros. Entende-se por que eram considerados uma "praga" e como se justificava afastá-los do centro. No mesmo ano em que "Nouquinha" foi preso, o feirante e pintor conhecido como "Índio" acabou na Delegacia de Jogos e Costumes, como nos conta a curta matéria:

Diligência efetuada por uma caravana composta dos investigadores Ezequiel, Walter e Alcebíades, lotados no posto policial das Docas, logrou êxito ao apreender uma lata de biscoito tamanho média, completamente cheia de maconha, em espécie e pequenos pacotes preparados.

A 'erva maldita' estava numa maloca situada no local denominado 'coroa' da feira livre de Água de Meninos, e seu dono é o gatuno conhecido pelo vulgo de 'Índio' [...]. (MACONHA, 1961, p. 3)

Mais uma vez não se tem a versão do acusado. No seu lugar, tem-se a informação de que este teria alegado uma grave moléstia e "pedia clemência à Polícia", o que demonstra a já conhecida sugestão da imprensa de que uma dificuldade na vida do indivíduo o impelia à prática do delito, colocando sob suspeita quem mais compartilhasse do problema. Além disso, "Índio" afirmou ser pintor, no que discordou tacitamente o noticiário acusando-o de ser, na verdade, "gatuno" "conhecido da Polícia, contando com várias entradas". 
Sonhos da diamba

Água de Meninos, onde "Índio" foi preso em 1961, e outras feiras e mercados soteropolitanos ficaram na memória da cidade, como a Feira do Sete, no areal que se estendia da Jequitaia ao sétimo armazém do porto, a Feira do Cortume, em frente à penitenciária e, a mais recente, São Joaquim. Mas, para parte das elites econômicas da cidade isso causava preocupação. Podia-se ler nas páginas da imprensa na época:

As feiras livres e os mercados tornaram-se o antro predileto de uma multidão de marginais. Rastejando-se na imundícia, portadores das mais estranhas sortes de mazelas e doenças, imiscuem-se às mercadorias, num incrivel desafio à saúde pública. (MERCADOS, 1958, p. 3)

Essa perspectiva ecoava, ainda nos fins da década de 1950, antigas concepções higienistas que classificavam as classes subalternas como "classes perigosas", possuidoras de atavismos que conduziam inevitavelmente ao crime e taras degenerativas capazes de contaminar a sociedade, fundindo controle social e saúde pública. (CHALHOUB, 2008; CUNHA, 1986; PESAVENTO, 2002)

Figura 2 - A feira de Água de Meninos retratada pela lente do Diário de Notícias

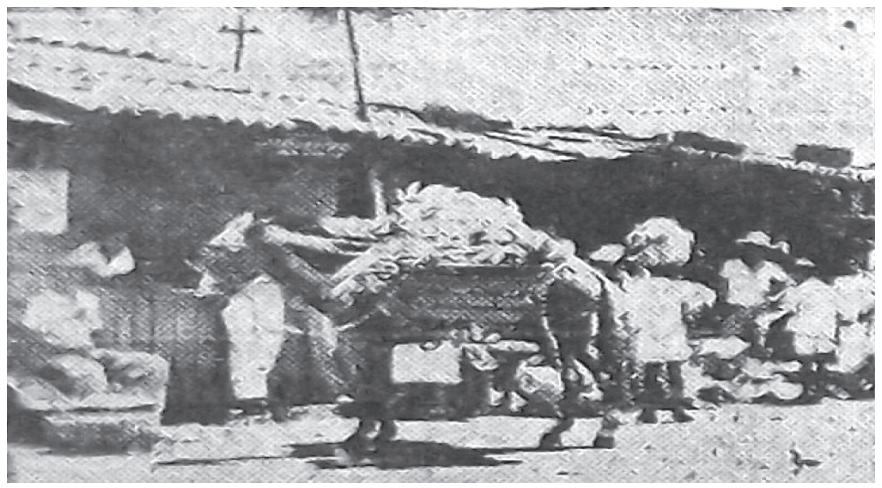

Fonte: AGUA (1958, p. 12). 
A imprensa da capital associou maconha à feira, sobretudo Água de Meninos, no bojo da campanha contra seu uso na década de 1950. Em 1952, por exemplo, A Tarde denunciou que Salvador havia se tornado "entreposto" de exportação de maconha vinda de Sergipe e Alagoas para Santos, Rio de Janeiro, o sul do país e até para os Estados Unidos através de um esquema que combinava os navios do Lóide, os trens da Leste e a feira de Água de Meninos. (ESTA, 1952, p. 3) Três anos depois repetiu um discurso idêntico:

Aqui na Bahia a polícia já teve oportunidade de apreender maconha, vinda de Sergipe ou Alagoas na feira de Água de Meninos, presumindo-se que existe mesmo uma quadrilha que atua no porto, em harmonia com tripulantes de navios do Lóide. (ACERTAM-SE, 1955, p. 5)

Para o periódico a feira fazia parte de uma rota de tráfico interestadual e internacional que tinha sua origem justamente nos estados considerados pelos especialistas e autoridades do proibicionismo como os principais produtores de maconha do Brasil: Alagoas e Sergipe. Outro dado também presente nesse discurso aparece nas matérias acima: a ideia de que a Bahia não era um estado produtor da droga, mas consumidor e centro de distribuição para outros estados, um entreposto comercial. (CARDOSO, 1958a) Ainda vale ressaltar o destaque dado em ambas as ocasiões aos "tripulantes de navios do Lóide", os trabalhadores maritimos, outra figura bastante recorrente nas considerações dos proibicionistas. Esses aparecerão logo mais. Por enquanto mais algumas linhas acerca das feiras.

$\mathrm{Na}$ verdade, desde a gênese da campanha contra a maconha no Brasil, feiras e mercados populares foram com frequência apontados como pontos de venda e uso:

Vi algumas vezes, quando criança, nas feiras semanais de Propriá, minha terra natal, à noite, ao cessar a vendagem, indivíduos se entregarem à prática de fumar a erva 
[...], sorvendo em austos profundos a fumarada apetecida, depois do que entrava o desafio ou o duelo poético; alguma vez a contenda tomava feição diferente, e exigia a intervenção da polícia para apaziguar os contendores exaltados. (DÓRIA, 1958, p. 5)

O testemunho é do já conhecido Rodrigues Dória, principal referência do proibicionismo da maconha no Brasil, em seu "Os fumadores de maconha: efeitos e males do vício". O artigo é de 1915, mas Dória se remete a fatos ocorridos em sua infância, o que torna o relato ainda mais significativo, pois nasceu em 1859.

Segundo Rodrigues Dória, nas feiras da cidade de Propriá, em Sergipe, eram recorrentes as intervenções policiais nas ocasiões em que usuários de maconha se reuniam para fumar e travar "duelo poético" depois do dia de trabalho ainda no século XIX, o que parece indicar a existência de uma percepção condenatória da maconha entre essas autoridades locais muito antes da criminalização oficial em 1932. Porém, em seu relato o hábito parece ser algo bastante público nessa localidade, os feirantes não estavam escondidos, mas em meio às barracas na feira "ao cessar a vendagem", ao alcance das vistas de uma criança.

A despeito de buscar num passado distante os elementos para conformar a imagem de problema de segurança pública que tentava imprimir para a presença da maconha nas feiras, devido ao seu potencial de provocar loucura, o médico deixa transparecer que, se desavenças ocorriam nessas ocasiões, não eram a regra, mas aconteciam "algumas vezes". As feiras são zonas de contato entre diferentes consumidores, provenientes de lugares sociais diferentes, mas nem por isso, impermeáveis às trocas simbólicas embutidas nas trocas materiais do comércio. Na feira higienizada e ordeira, simbolo de "modernidade", pretendida por médicos e autoridades, como o dr. Dória, não havia lugar para a maconha. Para eles, melhor se as crianças não presenciassem mais tal cena. 
Das feiras chega-se aos maritimos e os portos. Marujos, marinheiros, canoeiros, pescadores, doqueiros, estivadores e todos os trabalhadores ligados ao mar, sobretudo, os que labutavam nas docas e portos do litoral, mas também os que singravam os rios interioranos, como o São Francisco, foram acusados por especialistas e autoridades do proibicionismo da maconha de serem os principais difusores da "erva da morte" no Brasil. Se o negro africano introduziu, foram os marítimos que espalharam.

Segundo estas autoridades, a maconha entrava e saia de navios escondida em meio às mercadorias e, graças à falta de eficiente fiscalização nos portos, encontrava em terra seus distribuidores, alastrando-se pelas cidades. Para que o mecanismo funcionasse, argumentavam as autoridades, era necessária a participação ativa dos marítimos. Esses trabalhadores foram duplamente acusados, duplamente estigmatizados: além de fumar a "maldita", comercializavam-na, eram "maconheiros" e "traficantes". As propaladas consequências do uso da maconha se encaixavam perfeitamente no estereótipo pouco "civilizado" atribuído aos maritimos, historicamente pintados como beberrões, valentões e explosivos. (LINEBAUGH; REDIKER, 2008; SILVA, 2004)

O porto de Salvador, centro de um dos principais impulsos modernizadores da cidade na Primeira República, era uma região fundamental para a sua economia. Nele se dava a grande parte do comércio da capital e do estado em barcos de diferentes dimensões a serviço de pequenos comerciantes ou de poderosas firmas e companhias de navegação nacionais e estrangeiras. As transformações e melhoramentos na região portuária aumentaram o fluxo de pessoas, favorecendo o comércio popular e a intensificação da dinâmica cultural numa região da cidade que já apresentava grande diversificação social de longa data. (LEITE, 1996; PAIM, 2005) 
Sonhos da diamba

Décio Parreiras (1958, p. 249) em sua visita de 1949 tomou nota dos lugares apontados pelas autoridades baianas como preferidos para o comércio e uso da erva em Salvador:

o Mercado das Sete Portas; Água dos Meninos; Cais do Porto, principalmente junto ao Armazém 4; Praça Cayru; Cais da Alfândega e Rotunda, isto é, nas zonas freqüentadas por marítimos, embarcadiços e decaídas.

O chefe ali na região do Cais do porto, que controlava a venda para os marinheiros americanos da MacComarck, era um tal de "Shore".

O porto e seus trabalhadores na cidade da Bahia formavam uma fusão suspeita para as elites politicas locais, responsável por detonar 52 greves durante a Primeira República, juntamente com os empregados do transporte público e os operários da indústria têxtil. (SANTOS, 2001) Ainda se envolviam em manifestações populares no periodo posterior, como durante o amplo e pouco estudado movimento popular contra a carestia de vida na primeira metade dos anos 1950. (FREITAS, 1985) Se adicionadas essas características ao comportamento reprovável que esse grupo apresentava, aos olhos das elites mais conservadoras, conclui-se que não foi dificil lhes pregar o rótulo. Parece que diferentes preocupações convergiam nos clamores para uma atenção específica ao problema da maconha nas docas.

Interessante observar que na viagem de inspeção realizada pelo dr. Roberval Cordeiro de Farias, presidente da CNFE, à região Nordeste para estudar a mesma questão em 1943, surge um elemento novo. O Secretário de Segurança Pública, major Pulchério considerou que houve um aumento da gravidade do problema da maconha na cidade "[...] pela influência da presença neste porto de marinheiros americanos, de navios mercantes e de guerra". (FARIAS, 1958, p. 108) O major, no mesmo ano, 
havia tentado contribuir com os americanos, fazendo aprovar Decreto-Lei contra "os ruídos que impregnavam a cidade" e atrapalhavam a "batalha da produção" em meio ao "esforço de guerra", o que na prática justificou a ação policial sobre rodas de samba e festas de terreiro. (CRUZ, 2006, p. 37-44)

Estados Unidos era o país que capitaneava a "guerra às drogas" no plano internacional no período, dando especial ênfase à maconha numa forte campanha ideológica e policial sob as ordens de Harry Jacob Anslinger à frente do Federal Bureau of Narcotics, a agência antidrogas oficial. ${ }^{13}$ Porém, em Salvador na década de 1940 os norte-americanos não eram os capitães do combate à maconha, mas os marinheiros que aumentavam seu consumo na capital.

Essa presença dos "gringos" e seus contatos com as classes subalternas em Salvador foram registrados por Vasconcelos Maia num conto de $1946 .{ }^{14}$ Cilu, jovem e bela meretriz que fumava maconha contra uma depressão súbita que lhe acometia, é quem conduz a história. Natural de Sergipe, mas instalada na Salvador da Segunda Guerra Mundial, "fazia vida" num "sobradão sombrio do Pelourinho", em São Miguel de Baixo, conhecido como Mangue. Diante das incertezas e perigos da vida no mar em meio à guerra, aproveitavam como podiam a capital:

Nessa época, chegavam aos ouvidos das mulheres de Sergipe, tentadores convites da Bahia. A Guerra tinha estourado e diariamente chegavam navios estrangeiros ao por-

13 Apesar da liderança da campanha proibicionista no século XX, alguns estudos realizados por instituições oficiais nos Estados Unidos sobre o uso da maconha revelaram resultados distintos e manifestaram opiniões diferentes do discurso que o país tentava impor globalmente. (CARDOSO, 1994; LUCENA, 1958)

14 O escritor Vasconcelos Maia foi fundador da revista Caderno da Bahia nos fins da década de 1940, importante instrumento de consolidação do Modernismo nas expressões artísticas no estado. O conto "Mangue" é originalmente do livro Fora da Vida, de 1946. Devo a Tiago Groba a indicação desse texto. 
to de Salvador. Eram comboios compridos, comboios de guerra, entupidos de marujos, de homens jovens, ansiosos por mulheres e que, em terra, pagavam gordas somas por minutos de amor [...] Era ganhar prestígio a que conseguisse fisgar um oficial ou mesmo um marujo daqueles. Era uma caça diferente dos michês brasileiros, caça preciosa de dinheiro solto. Como gastavam! Desciam na Bahia depois de longas viagens perigosas, depois de prolongada abstinência, vinham sequiosos de prazer e gastavam tudo sem pena, com mulheres e álcool. Nunca sabiam se alcançavam o porto seguinte, entregavam-se desbragadamente ao gozo e às bebedeiras. (MAIA, 1964, p. 70-72)

Não eram nem de longe os estrangeiros que poderiam ter "salvado a raça", ter "desafricanizado" a Bahia, como pretendia parte das elites locais.

A realidade se torna ainda mais complexa através de um caso relatado pelo médico João Mendonça, representante da classe médica na Cefe. Com base na observação de um marítimo detento da Penitenciária do Estado, a qual era também diretor na década de 1940, pretendeu demonstrar "um caso muito frisante de homicídio por intoxicação aguda pela maconha". Contudo, também evidenciou os limites e contradições do modelo de "marítimo maconheiro e traficante" que apregoavam.

Era um marinheiro, tinha "preferência pela vida no mar", e sobre ele nos fala Mendonça (1958, p. 101):

Foi o caso que o $\mathrm{n}^{\circ} 392$, a fumar um cigarro de maconha, penetrou, com outros marinheiros, numa quitanda, á procura de cana. Um indivíduo, que ali estava, cortesmente, informa que aquela, entre suas próprias mãos, era muito boa. O 392 saca duma faca, e sem dizer mais nada, vibra um golpe na pessoa que o obsequiara com a informação. O homicida conhecia, apenas de vista, a vítima; com ela, nunca tivera o menor atrito. Desse modo, o delito realizou-se em condições de instantaneidade, sem luta, sem provocação, sem móvel mediato ou imediato e, circunstância de realce, o 392 nada se recorda do ocor- 
rido no espaço de tempo decorrido entre o delito e o seu acordar na prisão.

Segundo o psiquiatra, o indivíduo - despersonalizado e identificado pelo número "392" - após o consumo de maconha entra numa quitanda, pede uma bebida e, sem mais nem menos, esfaqueia outro indivíduo. Há uma ênfase nesse aspecto "instantâneo" do fato com o claro objetivo de reforçar a influência negativa do uso da droga: ele conhecia a vítima "apenas de vista" e agiu sem ao menos ser provocado. Depois de consumado o crime, que teria sido motivado exclusivamente pelos efeitos da maconha, o marinheiro não se recordava de nada.

As informações do dr. Mendonça são superficiais demais para tirar grandes conclusões. Superficialidade, aliás, claramente intencional, visto que estava tentando demonstrar as terriveis consequências do consumo de maconha para a segurança pública. Dessa forma, reduziu todo o acontecimento a uma única causa, justamente aquela contra a qual ele se empenhava. Contudo, essas poucas palavras trazem algumas informações.

Que motivos levariam um homem a aplicar uma facada em outro sem muita conversa? Os dois não eram desconhecidos, ao menos se conheciam "de vista" e, apesar do doutor afirmar que nunca tiveram "o menor atrito", poderiam estar envolvidos em questões variadas do cotidiano capazes de criar alguma antipatia entre eles. ${ }^{15}$ Outro dado significativo é o fato do acusado ter alegado que não se recordava de nada do que aconteceu. Pode ter sido o que se passou efetivamente, como também, pode ter sido uma tentativa do acusado de se livrar

15 Sidney Chalhoub (2008) foi um dos primeiros a chamar a atenção para esse aspecto numa leitura critica das fontes policiais, judiciais e da imprensa que frenquentemente atribuiam as brigas entre os trabalhadores a "motivos fúteis". 
da condenação alegando que a droga havia the tirado a sanidade e o controle sobre seus atos, o que poderia lhe isentar da responsabilidade penal. ${ }^{16} \mathrm{O}$ processo criminal instruído contra o detento 392, com certeza, esclareceria o "móvel" do crime, podendo até evidenciar que foram outros os motivos e não a maconha, mas infelizmente esse documento não foi encontrado.

Como o dr. Mendonça precisava de informações para instruir o pedido de livramento condicional, que teve o prof. Mário Leal como relator, procede ao "Exame psíquico" do 392 e nos dá algumas informações relevantes sobre a sua pessoa.

Exame psíquico - (Caráter. Mente). [...] Equilíbrio afeto-volitivo (disciplinado, boa capacidade de trabalho físico, casado, com filhos, corresponde-se muito com sua mulher e filho, para os quais envia todo dinheiro disponivel).

[...] Instinto de conservação, reprodução, gregário e seus derivados, bem controlados. Não há desvios sexuais nem aberrações sociais. Sabe ler e escrever regularmente e professa a seita rígida protestante. Não possui os estigmas próprios do vero delinquente, como se vê, nem as sociológicas de inadaptação, tão pouco as somáticas. (MENDONÇA, 1958, p. 102)

Salta às vistas a profunda incongruência entre o criminoso frio e irracional descrito anteriormente e essas conclusões do próprio médico. O indivíduo era "disciplinado" e com fortes laços familiares, com "instintos" "bem controlados", sem "desvios sexuais", alfabetizado, religioso e sem "estigmas de delinquência”. Como esse sujeito poderia ter cometido um homicídio daquele? Sagazmente, o dr. Mendonça usa essa contradição a

16 O artigo no qual João Mendonça apresenta o caso é de 1944. Ele informa que já fazia mais de dez anos do crime, o que coloca o fato sob a jurisdição do Código Penal de 1890. Num dos dispositivos que tratam da responsabilidade criminal, o Artigo 27, $4^{\circ}$, define-se que não eram criminosos "[...] os que se acharem em estado de completa privação de sentidos e de inteligência no ato de cometer o crime". (BRASIL, 1890) 
seu favor: só mesmo a maconha para impelir um homem "disciplinado" ao crime "sem motivo aparente".

É claro que o médico se esforça para enquadrá-lo numa explicação possivel. Admite inicialmente traços de epilepsia. $\mathrm{O}$ crime poderia ser explicado por e como uma doença. Mas reconhece que o 392 não se enquadra nesse perfil criminológico e explica definitivamente pelos efeitos da maconha:

No caso vertente [...] o 392 praticou um crime cujas características jurídicas são as do epilético, sem o ser [...] Por outro lado, o que se sabe da maconha [...] é suficiente para concluir-se que o 392 praticou o crime num estado de embriaguez motivado pela maconha [...]. (MENDONÇA, 1958, p. 103)

O doutor deve ter levado a melhor. Apesar de não sabermos o resultado do pedido de livramento condicional do detento naquela ocasião, sem dúvidas ele deve ter convencido sua audiência, formada por médicos e autoridades da Sociedade de Medicina Legal, Criminologia e Psiquiatria da Bahia, onde proferiu a comunicação transformada em artigo, dos "perigos sociais da maconha".

O importante é notar o reconhecimento do próprio médico de que as características pessoais do detento não apontam para um "maconheiro" nos moldes apregoados pelos especialistas, principalmente sendo ele um maritimo. Esse tinha família e, pelo que parece, não era desprezado por ela, se correspondendo regularmente e enviando todo dinheiro que podia, não era analfabeto e era religioso. São indícios de que, por trás da aparente segurança da ideia do "problema da maconha" defendida pela sua classe, os próprios cientistas revelavam fissuras no modelo de personalidade do usuário que buscavam construir. Mesmo não mudando a opinião de que a maconha era um "problema" que precisava ser exterminado, o consenso 
absoluto de que todo "maconheiro" era igualmente um louco degenerado sem laços sociais não predominava entre os especialistas da questão por que a realidade por eles observada questionava esse modelo.

$\mathrm{Na}$ Salvador da época, a maconha dava trabalho à polícia e "até artistas estrangeiros traziam amostras da 'Cannabis sativa", como dizia um jornal:

Exemplo concreto chega-nos agora, através da informação recebida pelo repórter através da Delegacia Auxiliar: Lia Ray e seus cubanos estão implicados no tráfego proibido da 'Maconha'.

De fato, chegando àquela repartição, vimos os jovens músicos detidos a prestar esclarecimentos, vez que a Polícia, que ora intensifica a campanha repressiva à 'Diamba', ou ainda ao 'cachice', tem levado a efeito uma série de diligências nesse sentido, culminando com a desta madrugada, quando o investigador Queiroz encontrou numa das malas dos artistas farto material, no Palace Hotel. (APREENDIDA, 1951, p. 3)

No início da década de 1950, numa madrugada de agosto de 1951, os músicos cubanos integrantes do conjunto "Mambo Dandies", que acompanhava a cantora Lia Ray, foram surpreendidos no Bar Tabarís, no centro de Salvador. Francisco Ferreira, Carlos Soarez, Luiz Belmude, Rafael D'avila e Boby Colon, dois negros e três pardos, sequer imaginavam àquela altura da noite que veriam o dia 2 de agosto nascer na Delegacia Auxiliar e não no Palace Hotel por conta de certa quantidade de maconha que guardavam consigo. O outro motivo da suspeita era explicada por outro noticiário: alguns deles tiveram contato com suspeitos no tráfico de entorpecentes. (MAMBOS, 1951)

$\mathrm{O}$ uso da maconha também era difundido em Cuba, as ocasiões de uso coletivo, que eram denominadas pelos especialistas do proibicionismo, no Brasil, de "assembleia" ou "clube 
de diambistas", lá eram chamadas de "confradia" ou "bonche" e o cigarro coletivo lá havia recebido o nome de "chicharra". (PARREIRAS, 1958, p. 273) O motivo da prisão talvez não fosse estranho aos "mambos" haja vista que a planta já despertara a atenção de médicos e autoridades da ilha algum tempo antes.

A maconha era tão perseguida lá quanto aqui, sobretudo devido à forte influência dos Estados Unidos no país. Basta ver o título do artigo de um importante médico cubano, o dr. Luiz Muniz Ângulo, para se fazer uma ideia da opinião geral da classe médica sobre o assunto: "A maconha e o instinto de agressão". (ÂNGULO, 1948) A ideia aqui é o poder que a erva possuiria para conduzir o homem de volta ao "estado de natureza", ao seu estado "selvagem", fora do alcance das "normais morais", liberando o seu "instinto de agressão".

Depois de prestarem depoimento, que contou com a não tão estranha presença do psiquiatra João Mendonça a submeter "[...] os jovens a testes psicológicos [...] no sentido de se poder apurar a cumplicidade dos mesmos", foram liberados pelos investigadores. (APREENDIDA, 1951, p. 3) Nota-se com clareza a suma importância de um dos agentes sociais envolvidos na construção do "problema da maconha" no século XX: o médico, nesse caso um psiquiatra, o dr. João Mendonça. Era o cientista capaz de extrair culpabilidade com suas técnicas psicológicas, denotando a visão patologizadora do hábito, transformado em "vício", passivel da intervenção de um "especialista". Nada de anormal se, ao ler a matéria, nota-se alguns dos principais termos do proibicionismo das drogas no Brasil: "entorpecentes", "viciados" e "tóxicos".

Não há registros de que os músicos tenham provocado alguma desordem em Salvador ou assassinado alguém absolutamente sem motivo ou ainda que tenham cometido algum crime contra a propriedade. Mas todo um aparato de controle 
e constrangimento foi posto em funcionamento ao ser evidenciada a relação dos artistas com a maconha: imprensa, polícia (que revistou seus quartos e pertences no Palace Hotel) e a psiquiatria.

Os artistas estavam no Tabarís, que era bar, "dancing" e um dos "cabarés" mais famosos da cidade nas imediações da Praça Castro Alves. Era ponto de divertimento popular na época e não angariava muitos aliados na imprensa. As autoridades policiais acusavam o Tabarís de fazer parte da "engrenagem diabólica" da "aquarela do crime" em Salvador já fazia tempo. (AQUARELA, 1940, p. 8) Não é dificil de conceber por que se tornaram "suspeitos" de consumo de drogas: cinco artistas negros e mestiços se divertindo às três e meia da madrugada num dos lugares mais populares e suspeitos da cidade, onde fariam "contato" com "suspeitos de tráfico". Enquadravam-se com facilidade no modelo de "suspeito" de "maconheiro" das autoridades e da imprensa de Salvador.

Figura 3 - Os músicos cubanos na Delegacia Auxiliar

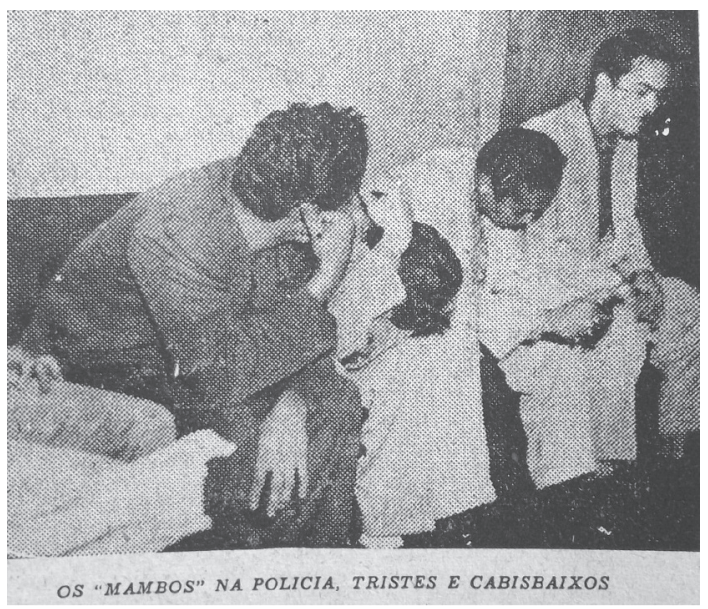

Fonte: MAMBOS (1951, p. 5). 
Mais um episódio ocorrido na tarde do dia 2 de outubro de 1940 em Salvador pode jogar um pouco mais de luz sobre essas e outras questões acerca do aparato repressivo policial direcionado para os usuários pobres, demonstrando como as diversas personagens agiam na realidade, se relacionando de diferentes maneiras com a legislação criminalizadora e o discurso proibicionista apresentados até aqui. Tudo começou quando:

[...] os indivíduos João Lima P., José Jerônimo da S. e Talvino Rosendo de O., foram surpreendidos a vender e consumir certa erva entorpecente de nome Maconha, hoje, no Mercado do Ouro, coisa que constitui contravenção às disposições que asseguram a incolumidade da saúde pública, conforme preceitua o Código Penal no art. 159 [...]. (ARQUIVO PÚBLICO DO ESTADO DA BAHIA, 1940, p. 1)

Ao que tudo indica, José Jerônimo e João Lima se encontravam no Mercado do Ouro quando foram detidos pelo guarda civil $\mathrm{n} .{ }^{\circ} 357$, que anteriormente deteve Talvino, tendo esse implicado os dois. Foram todos os três conduzidos para a Delegacia de Jogos e Costumes (DJC) e lá citaram mais dois homens na situação, que foram levados a depor na mesma delegacia. Além dessas personagens, entraram em cena na ocasião dois representantes da medicina legal e criminal, os peritos Eduardo Bizarria Mamede e José Maria Penna Corrêa. Médicos, polícia e usuários de maconha se encontravam na capital, numa de suas primeiras vezes.

O documento não nos oferece muito da visão que os próprios acusados compartilhavam sobre a maconha e seu uso psicoativo, pois as suas falas se encontram circunscritas às perguntas do delegado, mas é revelador. É importante notar, de início, que a portaria acima evoca o art. 159 do Código Penal em voga na época, que era o de 1890, já que o código aprovado 
naquele ano de 1940 só substituiria esse em 1942. Entretanto, o Código Penal em questão ao se referir às drogas como "substâncias venenosas", no dispositivo citado, não menciona quais seriam essas, muito menos inclui a maconha. Porém, se não estabelecia as substâncias, conferia relativa liberdade para as autoridades policiais, o Código lhes permitia incluir nessa categoria "substância de qualquer dos reinos da natureza". ${ }^{17}$

O referido art. 159 também não aponta a prisão como penalidade para a contravenção, apenas a multa, não prevendo expressamente a punição para quem consumia as "substâncias venenosas", somente para quem as vendesse ou ministrasse em outrem sem autorização legal. Para o delegado, a contravenção se dava no terreno da saúde pública, mas como definia aquele diploma, que, como dito, não especificava nenhuma substância proibida nem a prisão como recurso. Dessa forma, a prisão dos acusados era ilegal, pois, ainda que a maconha pudesse estar entre as "substâncias de qualquer dos reinos da natureza", a privação da liberdade não achava fundamento no dispositivo evocado pelo delegado.

A perspectiva da autoridade, entretanto, parecia estar inspirada pela repercussão da legislação proibicionista editada ao longo da década de 1930. O delegado pergunta a um dos acusados se este "[...] já conhecia a 'maconha' sabendo-a entorpecente e proibido o seu uso" (ARQUIVO PÚBLICO DO ESTADO DA BAHIA, 1940, p. 10), onde se percebe que não desconhecia que o uso da maconha, especificamente, estava proibido. Ainda atesta essa possibilidade o emprego da expressão "entorpecente" que só apareceria em legislação posterior a 1890, a exemplo do Decreto n. 4.294 de 1921, ainda como uma qualidade da

17 O art. 159 do Código Penal de 1890 estava inserido no Capítulo III, que tratava dos crimes contra a saúde pública, do Título III (Dos crimes contra a tranquilidade pública). 
“substância venenosa" ou no Decreto-Lei n. 891 de 1938. Nesta última norma a expressão foi ampliada para abarcar todo e qualquer psicoativo como demonstra o seu título, "Lei de Fiscalização de Entorpecentes". Esse desenvolvimento jurídico da criminalização da maconha chegou aos seus ouvidos, mesmo que ele não se apropriasse diretamente dele no caso.

Essa coexistência de noções de diferentes normas jurídicas a fundamentar e orientar a ação policial sobre a maconha no começo da década de 1940 em Salvador não deve ser tomada apenas como uma defasagem em relação ao corpo jurídico sobre o qual se assentava a criminalização, visto que há indícios de que a autoridade conhecia as atualizações legais. É mais provável que evidencie uma falta de especialização da questão, que parecia ainda não ter se transformado na entidade autônoma criminal que a "toxicomania" vai assumir, sendo por isso incluída genericamente pelo delegado na categoria de "crimes contra a saúde pública", ao lado do espiritismo, da cartomancia e do curandeirismo, como equiparava o primeiro Código Penal republicano. Nos anos 1940 a Bahia se tornaria, nos discursos dos agentes do combate à maconha no Brasil, um modelo de repressão, mas isso ainda não se verificava naquele momento. Além disso, ainda não existia um órgão especializado no assunto no estado, que seria instituído poucos anos depois: a Comissão Estadual de Fiscalização de Entorpecentes.

Os acusados, por sua vez, que frequentavam e viviam na cidade baixa, lançaram mão do que podiam para se inocentarem. A região da zona portuária na cidade baixa, onde se situava o Mercado do Ouro, o cais e o Moinho da Bahia, cenários das prisões que levaram a esse inquérito, era de grande concentração das classes subalternas de Salvador. Era próxima ao Bairro Comercial, onde existia uma guarda noturna desde a Primeira República para proteger os bens da Federação do Co- 
mércio, mas de intensa atividade de ambulantes e pontilhada de feiras e mercados populares.

Os dois pernambucanos e o alagoano envolvidos no caso vieram para Salvador dentro de um fluxo migratório que ia se intensificando, devido ao potencial de atração que as cidades maiores passavam a exercer sobre as populações das menores. Ao chegar a Salvador, na maioria das vezes iam morar com parentes ou conhecidos que por aqui já estavam, expandindo as áreas periféricas da cidade e proliferando os "mocambos", ou poderiam ocupar quartos nos antigos casarões coloniais do centro, transformados em moradias coletivas pelos pobres desde muito tempo. Em geral, engrossavam o contingente de trabalhadores informais da cidade, que as autoridades preferiam denominar de "vagabundos", "decaídas", "desordeiros", "vadios" e "maconheiros". Mas quem eram aqueles sujeitos?

João tinha 31 anos, era natural de Pernambuco, carpinteiro, sabia ler e escrever e não possuía residência fixa em Salvador. Disse que veio para a capital para melhorar de vida, buscando trabalho na sua profissão, mas não conseguindo, estava exercendo a atividade de trapeiro. No esforço de se livrar das acusações, João afirmou que "não sabia que o seu companheiro trazia aquilo [a maconha] consigo, muito menos que ele a vendia", apenas tendo conhecimento que era conseguida num depósito, "por onde passam frequentemente sergipanos e alagoanos" e que "o vegetal em apreço só existia no estado de Alagoas", onde havia estado durante algum tempo. (ARQUIVO PÚBLICO DO ESTADO DA BAHIA, 1940, p. 2)

Ele se defendeu das acusações implicando outros dois sujeitos, "Serrinha" e "Galego". Segundo seu depoimento, os dois haviam sido detidos no mesmo dia, momentos antes pelo mesmo policial que o prendeu, porém foram liberados pelo guarda "sem ordem de autoridade superior" somente "porque 
diziam que quem tinha a erva era "Capenga". Transferindo a culpa para "Serrinha" e "Galego", ainda menciona ter ouvido do primeiro que, tendo sido preso há "mais ou menos um mês", "zombou da polícia" fumando maconha "dentro do próprio xadrez". (ARQUIVO PÚBLICO DO ESTADO DA BAHIA, 1940, p. 3)

O outro envolvido era José Jerônimo, natural de Sergipe, padeiro, analfabeto e também sem residência certa. Disse ter vindo de São Paulo para Salvador após a "revolução paulista". Por conta das dificuldades em conseguir empregar-se no seu oficio achava-se alocado como trapeiro, o que o levou a conhecer João Lima. Em sua versão, teria encontrado “[...] dentro de uma lata de manteiga pequena, umas folhas de si conhecidas", contudo não tinha conhecimento da "nocividade das ervas", as quais foram mostradas aos "individuos apelidados de 'Galego' e "Serra Grande". Estes teriam voltado "agora propondo a compra do restante das ervas", o que ele aceitou, porém não fora pago, "pois os compradores o calotearam". (ARQUIVO PÚBLICO DO ESTADO DA BAHIA, 1940, p. 4-5)

Tudo teria começado com a prisão de Talvino Rosendo ou "Capenga", como era mais conhecido no cais do porto. Com dezoito anos, era natural de Alagoas, analfabeto, "vendedor ambulante de laranjas" e residente na Calçada. "Capenga" coloca mais uma peça que pode nos ajudar a desbaratar a trama do ocorrido:

[...] quando passava nas proximidades do Moinho da Bahia encontrou 'Galego' e 'Serra Grande', apanhadores de trapo, fumando cigarros que lhe eram desconhecidos, que lhe induziram a também fumar, tendo 'Galego' lhe dado uma ponta do dito cigarro para experimentar; que diante disso resolveu levar o cigarro para casa, colocando-o no bolso e se retirando dali, para momentos depois ser detido pelo guarda civil de serviço nas Docas, que lhe declarou que o respondente estava sendo por 'Galego' e 'Serra Grande' acusado de distribuir maconha [...]. (ARQUIVO PÚBLICO DO ESTADO DA BAHIA, 1940, p. 6) 
O guarda, então, encontra em seu bolso uma "ponta de cigarro de maconha" e lhe pergunta "quem mais traficaria com o narcótico", ao que ele responde: “[...] uns trapeiros que viviam lá por São Joaquim, um dos quais tinha achado as folhas em uma lata, nas proximidades do Mercado do Ouro". (ARQUIVO PÚBLICO DO ESTADO DA BAHIA, 1940, p. 6) Talvino foi obrigado pelo oficial a ir a São Joaquim e apontar os trapeiros, indicando dois homens imediatamente detidos. Foram assim, todos conduzidos à delegacia. É preciso entender o que teria se passado até aqui.

João Lima afirmava ser inocente, alegava desconhecer totalmente a existência da maconha e o comércio da erva feito por José Jerônimo, acusa "Serrinha" de fumar no xadrez e ainda faz críticas ao oficial que lhe prendeu por ter soltado este e "Galego" "sem ordem superior", sugerindo algum tipo de conluio. José Jerônimo, que não negou conhecer a erva, mas disse desconhecer sua possivel "nocividade", assumiu ter a vendido para "Galego" e "Serra Grande", sendo, no entanto, "caloteado" por eles. Já "Capenga", declarou ter sido acusado injustamente por estes de "distribuir maconha", que os encontrou a fumar "cigarros desconhecidos", dos quais levou uma "ponta", mas não fumou; além de implicar "Galego" e "Serra Grande", delata os outros dois por ter sido obrigado pelo policial. E, por fim, repete uma versão muito próxima da contada por José Jerônimo para explicar o acesso à droga. Conhecendo os outros acusados agora.

"Serrinha", também referido como "Serra Grande", batizado Luiz Rodrigues, e "Galego", cujo nome era Waldemar Ferreira, eram vizinhos, moravam na Calçada, assim como Talvino. "Galego" era o baiano da história, tinha dezoito anos, era açougueiro e alfabetizado. "Serrinha" era pernambucano, tinha dezenove anos, trabalhava de trapeiro e também sabia ler e 
escrever. Eles já haviam sido presos antes do ocorrido e, supostamente, o segundo até teria fumado maconha no xadrez da Delegacia de Jogos e Costumes (DJC), mas não admitiu em depoimento. Voltaram à DJC no dia 12 de outubro, dez dias após a prisão dos demais, sob as ordens do delegado, pois foram citados no caso.

"Galego" foi o mais sucinto e procurou se eximir da culpa afirmando sobre o motivo da prisão que não estava envolvido "[...] senão como experimentador pela primeira vez da erva 'maconha', a qual the fora dada por seu colega de nome Luiz Rodrigues". Admitiu conhecer José Jerônimo, porém alegou "ignorar tenha ele achado erva entorpecente" e negou que a tivesse comprado, "lhe sendo ela desconhecida até aquela data". (ARQUIVO PÚBLICO DO ESTADO DA BAHIA, 1940, p. 9)

Luiz é quem traz as peças finais do enredo. Segundo seu depoimento, naquele dia 2 de outubro, um indivíduo que conhecia "de vista", mas sabia "ser também trapeiro"

[...] apareceu com uma erva entorpecente de nome 'maconha', sua conhecida, propondo ao respondente comprar da mesma e experimentá-la, fumando-a, proposta essa que foi aceita pelo respondente, que a comprou em quantidade de três mil réis; que foi detido por um guarda civil nas proximidades do Moinho da Bahia, juntamente com o seu colega de nome Waldemar Ferreira M., alegando o policiador que o fazia em virtude de estarem o respondente e seu colega a fumar 'maconha', coisa que não negou ao guarda, como também não nega aqui, tendo sido depois postos em liberdade. (ARQUIVO PÚBLICO DO ESTADO DA BAHIA, 1940, p. 10)

"Serrinha" ainda disse mais: afirmou ter oferecido a maconha ao colega "uma vez, precisamente quando foi detido pelo guarda", reconheceu que "sabia-a de uso proibido" e informou que o trapeiro com quem a adquiriu a trouxera de Alagoas "[...] onde é nativa e para onde aquele individuo se transporta fre- 
quentemente a buscar a erva”. (ARQUIVO PÚBLICO DO ESTADO DA BAHIA, 1940, p. 10)

Cruzando os depoimentos, a sequência dos acontecimentos parece ter sido a seguinte: o guarda civil de serviço na região portuária de Salvador encontra Waldemar e Luiz a fumar nas proximidades do Moinho da Bahia, os enquadra e interroga; os dois acusam Talvino, para quem haviam dado uma "ponta" do cigarro momentos antes, de ser o "distribuidor" da erva; o policial os libera e segue no encalço de Talvino, encontrando-o na mesma região, pois era onde trabalhava; este, conhecendo a relação comercial entre "Serrinha" e José Jerônimo, levou o guarda a prendê-lo junto com João Lima.

Há detalhes que podem indicar a existência de algum conflito. Em primeiro lugar, trabalhavam dividindo o mesmo território citadino, a Cidade Baixa, e deveriam se cruzar o dia inteiro por várias vezes. Lembre-se que dos cinco acusados, três eram trapeiros, ou seja, catavam objetos nas ruas, plásticos, papéis, papelão, metais, sucatas, etc. para vender em depósitos e ferros-velhos. Os outros dois eram um açougueiro e um vendedor ambulante, não sendo improvável que este também exercesse a atividade em alguns momentos da sua movimentação diária. Os dois acusados que admitiram vender e comprar a maconha, José Jerônimo e "Serrinha" eram trapeiros. A disputa pelos materiais descartados que seriam vendidos ou pelos espaços daquela região da cidade onde recolhiam esses materiais poderia, por exemplo, ter gerado algum tipo de conflito entre eles. Suposição, mas isso explicaria, em parte, as trocas de acusações.

Outra questão que revelaria um possivel conflito é a transação da erva feita pelos dois trapeiros. Enquanto José Jerônimo diz ter a encontrado ocasionalmente e decido vendê-la por proposta de "Galego" e "Serrinha", este último afirma que 
a iniciativa partiu de José, o transformando em um traficante interestadual de maconha trazida frequentemente de Alagoas.

Discordam em outro ponto relativo a essa transação: "Serrinha" sustenta que pagou "três mil réis" pela droga, enquanto José Jerônimo diz que "nada recebeu" e o chama de "caloteiro". Pode ter sido um artifício do segundo para minimizar as consequências da sua ação de vender a maconha, mas pode também indicar ter havido um desentendimento entre eles, resultando nas acusações.

Não deixa de chamar atenção as conexões dos depoimentos dos acusados com ideias que se encontravam presentes também no discurso do proibicionismo da maconha na época. Pode-se citar a afirmação de João Lima de que a erva "só existe em Alagoas" e a alusão à presença de sergipanos e alagoanos no depósito onde se conseguia maconha. Para "Serrinha" o estado de Alagoas era o seu centro de produção, pois lá "é nativa”. Acontece que ambos eram pernambucanos, residindo há pouco tempo em Salvador e podem ter vivenciado uma repressão anterior à maconha em Pernambuco, pois, no estado, as primeiras prisões envolvendo a droga se deram na capital no início da década de 1930, um ano após a sua criminalização. (LUCENA, 1958)

Desde o início da década de 1930 o médico do Serviço de Assistência a Psicopatas de Pernambuco, dr. José Lucena, realizava experiências com usuários de maconha para estudar os seus efeitos, divulgando suas conclusões na publicação periódica do órgão no qual trabalhava. Outro dado é que o médico pernambucano Eleyson Cardoso integrava desde os anos 1930 a CNFE. O cotidiano de vigilância que viveram, mais do que a leitura dos artigos médicos e jurídicos sobre o assunto, deve ter os colocado em contato com esse discurso condenatório da 
maconha, o qual supunham fazer sentido aos ouvidos das autoridades policiais.

Nesse sentido, é possivel entrever que, se não era perseguida diligentemente há tanto tempo quanto na capital pernambucana, naquele ano de 1940 o consumo de maconha já era algo não tolerado pela polícia soteropolitana. Nos depoimentos surgiram referências a outras prisões além daquela que motivou o inquérito. Como nos contou "Serrinha", o policial que deteve ele e "Galego" próximo ao Moinho da Bahia, alegou que "o fazia em virtude de estarem a fumar maconha". Ou seja, o uso de maconha já era causa de detenções, sendo a sua proibição algo conhecido das autoridades da capital, que lhe dispensava considerável atenção, pois somente as nossas cinco personagens estiveram envolvidas em três prisões em mais ou menos um mês.

Outro ponto significativo é "Galego" ter afirmado que o seu papel no fato foi de mero "experimentador pela primeira vez", negando reiteradamente envolvimento no comércio da droga. Isso evidencia uma tentativa, que não era infundada ou mesmo aleatória, de se distinguir do que viria a ser conhecido futuramente como "traficante". Segundo o Decreto-Lei n. 891 de 1938, tanto quem consumia quanto quem vendia estava sujeito à mesma penalidade, ambos eram criminosos, mas na prática parece que havia alguma diferença a ser considerada pelas autoridades na resolução da questão.

Ser "experimentador pela primeira vez" significava não ser vendedor nem ser um "intoxicado habitual", um "toxicômano". Para "Galego", na situação concreta, a melhor saída era ser considerado um usuário de primeira viagem, pois para o traficante a determinação legal da pena de um a cinco anos poderia ser seguida mais fielmente e para o toxicômano a ordem era a 
internação em "hospital para psicopatas". ${ }^{18}$ Ele foi preso por uso de maconha alguns dias antes da prisão que deu origem a esse inquérito e posto em liberdade no dia seguinte, provavelmente argumentou o mesmo, que provavelmente tinha ouvido de outros "maconheiros" que haviam passado pela experiência. Já tinha dado certo uma vez, poderia dar certo de novo.

Para ter certeza de que se tratava de maconha era preciso a confirmação da ciência. Ficou, então, a cargo dos peritos criminais Eduardo Bizarria Mamede e José Maria Pena Corrêa o exame da maconha encontrada com os acusados. O resultado, o auto de exame toxicológico, é uma sintese do que se sabia à época sobre a maconha através de estudos nacionais e estrangeiros. O dr. Mamede, inclusive, que exerceu durante algum tempo o cargo de prefeito da cidade de Santo Amaro, nomeado em 1931 pelo interventor Juracy Magalhães (TAVARES, 2001), ${ }^{19}$ juntaria sua experiência como perito e os estudos sobre o assunto para publicar o artigo "Maconha: ópio do pobre" em 1945. Além do "estudo do material enviado", os peritos buscaram responder às perguntas feitas pelo delegado no intuito de instruir o inquérito: a) "se tem a mesma efeitos nocivos á saúde, sobretudo como entorpecente" e b) "se é possivel dizer se ela é nativa neste Estado". (ARQUIVO PÚBLICO DO ESTADO DA BAHIA, 1940, p. 11)

Para responder à primeira questão os peritos, primeiro, concluem se tratar de maconha: "embora sem elementos de

18 O Capítulo III do Decreto-Lei n. ${ }^{0} 891$ de 1938 versa especificamente sobre a internação e a interdição civil do chamado "toxicômano". Segundo o Decreto-Lei, este era afetado por uma "doença de notificação compulsória, em caráter reservado, à autoridade sanitária local”, não sendo permitido o seu tratamento em domicílio, passível de "internação obrigatória". (BRASIL, 1938)

19 Eduardo era irmão de Jurandir Bizarria Mamede, tenente ativo no golpe da Revolução de 1930, tendo ele também participado do movimento no Nordeste. 
precisão científica absoluta, acreditam os peritos ser o vegetal examinado uma das variedades da Cannabis sativa, provavelmente a 'indica"'. Mesmo reconhecendo notáveis propriedades terapêuticas contra "[...] gastralgias, dores de dentes, cólicas uterinas, [que] como por encanto, são varridas do campo sensitivo-sensorial" (ARQUIVO PÚBLICO DO ESTADO DA BAHIA, 1940 , p. 12) e afirmando "[...] parecer paradoxal que alguns sintam, como efeitos da maconha, aquele euforismo, aquela sensação de rara felicidade e em outros o seu resultado imediato seja uma excitação que é uma perigosidade manifesta", os dois peritos sentenciam:

Entorpecente ou excitante [...], essas duas propriedades tornam a maconha altamente nociva á saúde e extremamente perigosa à sociedade. Mesmo se aproveitadas algumas falazes propriedades terapêuticas (entre as quais a analgésica), o seu uso arbitrário seria o primeiro passo ao ingresso inevitável ao vício. (ARQUIVO PÚBLICO DO ESTADO DA BAHIA, 1940, p. 14)

$\mathrm{Na}$ opinião dos doutores se tratava de maconha, ainda que não tivessem "elementos de precisão absoluta" para garantir, seria o material apreendido com os acusados uma variedade da Cannabis, que supõem seja a indica. Reconhecem resultados positivos do seu uso medicinal contra dores de estômagos, dores de dente e cólicas, aliviando o sofrimento do paciente de forma surpreendente, "como por encanto". Suas considerações também nos deixa entrever que àquela altura o discurso médico admitia que os efeitos psicoativos da maconha poderiam ser diversos: em alguns apenas "sensação de felicidade", em outros uma perigosa "excitação imediata". Contudo, seria exatamente essa característica "paradoxal" que the tornava muito "nociva à saúde" e "perigosa à sociedade". O "uso arbitrário", ou seja, 
sem a devida supervisão médica, ainda que terapêutico, levaria inevitavelmente "ao vício".

Por fim, em resposta à segunda pergunta do delegado da DJC, recorrem ao trabalho de um conhecido nosso:

Rodrigues Dória, provecto professor de Medicina Legal da Faculdade de Direito da Bahia, despertado pelas referências de Bentley, dedicou-se ao estudo da questão, concluindo por assegurar que a maconha não é brasileira, tendo sido trazida em várias das levas de escravos que aportavam às nossas aldeias e cidades litorâneas. O vegetal e o vício que logo souberam os índios apreciar, cedo haveriam de disseminar-se, para atingir, por fim, as camadas mais humildes do nosso povo. [...] Sob a denominação de 'fumo de Angola', era familiar em toda costa noroeste da África. Vegetal de cerca de um metro a um metro e meio de altura é encontrada, em relativa abundância no nordeste baiano, nas proximidades da região de Tucano, no interior dos estados de Sergipe, Alagoas, parte de Pernambuco [...]. (ARQUIVO PÚBLICO DO ESTADO DA BAHIA, 1940, p. 14-15)

Como se pode acompanhar, o auto de exame toxicológico que instruiu este inquérito foi além do que solicitou o delegado da DJC.

Os peritos foram buscar em Rodrigues Dória a base para responder às questões da autoridade policial, apresentando neste trecho algumas das principais ideias defendidas pelo médico em 1915: a origem africana da maconha no Brasil, sua predominância na região Nordeste e o perfil de classe dos usuários. Se o delegado pretendia saber se a erva apreendida era nativa na Bahia, eles responderam afirmando a possibilidade, pois seria encontrada "em abundância no nordeste baiano" na "região de Tucano", como também poderia ser encontrada em outros estados da região Nordeste, como também afirmava Dória. 
No entanto, sua origem histórica não seria em terras brasileiras, mas sim na "costa noroeste da África", onde era "familiar" e conhecida como "fumo de Angola". Fora trazida para este lado do Atlântico "em várias levas de escravos" africanos, tendo sido apreciada pelos povos indígenas e, então, disseminada nas "camadas mais humildes do povo". Da origem africana para predominar entre as classes subalternas no Brasil, sobretudo, do Norte e Nordeste. Ideias presentes em Rodrigues Dória que ecoam neste documento produzido 25 anos após o artigo fundador do proibicionismo brasileiro da maconha. Interessante observar que os peritos assinalam a participação do índio e do africano no processo, mas nada dizem sobre os europeus, se também apreciaram, se a cultivaram, se contribuíram para disseminar o hábito por aqui.

Através do inquérito policial envolvendo João Lima, José Jerônimo, "Capenga", "Galego" e "Serrinha" percebeu-se como as diversas questões tratadas até aqui se materializaram na realidade, num confronto entre usuários, autoridades policiais e cientistas. Identificou-se como a legislação proibicionista poderia determinar o trabalho policial e como esta ainda não estava muito organizada na cabeça das autoridades. Também ficou claro que não apenas os repressores se apropriavam dela, mas também os usuários, encontrando na prática as brechas legais que poderiam lhe inocentar ou, ao menos, minimizar as consequências do problema. E com o parecer dos doutores foi possível visibilizar a extrema sintonia desse aparato repressivo em relação ao discurso do proibicionismo da maconha construído pela medicina.

Como se tem visto, o discurso de combate à maconha acusou, via de regra, apenas os pobres num evidente esforço de transformar criminalização das drogas em instrumento de repressão e controle das classes subalternas no Brasil. Porém, 
o dr. Roberval Farias nos dá indícios de que os usuários não se encontravam apenas na "mais baixa escala social", informando em seu relatório de 1943 que na Bahia o uso de maconha já era "feito por indivíduos de categoria social mais elevada". Entretanto, ao contrário da grande atenção que dispensou na listagem de centenas de nomes de "maconheiros" pobres e no mapeamento de lugares em diferentes cidades de vários estados onde esses fumavam, coincidindo com os lugares que trabalhavam, moravam e se divertiam, não aprofundou esse ponto, pois: não citou nomes de "maconheiros" "de categoria social mais elevada" nem os lugares onde fumavam.

É bem verdade que há uma imensa escassez sobre esse ponto da questão. Todo o discurso e prática do proibicionismo brasileiro da maconha elegeram as classes trabalhadoras da sociedade como alvo da acusação de "maconheiros" e do estigma que imprimiam na mesma. Era o "ópio do pobre", como também se referiam à maconha os especialistas. (MAMEDE, 1945, p. 71) A expressão, por um lado, aludia ao fenômeno da difusão do seu uso entre as classes subalternas e, por outro, à estratégia médica de transferência dos efeitos do ópio para a maconha. Com isso se naturalizava a ideia do "entorpecimento", da "idiotização" ligada aos seus efeitos psicoativos, pois eram essas as consequências do consumo do ópio, segundo os médicos e farmacólogos. Ser designada como um "vício deselegante" é uma evidência das linhas gerais sob as quais se assentava a condenação. Opunha-se aos "vícios elegantes" das elites, das camadas mais abastadas da sociedade, inspirados nos hábitos psicoativos da belle époque parisiense. (PERNAMBUCO FILHO; BOTELHO, 1924) E entre esses, a maconha não teria ocupado um lugar de destaque. Prefeririam a morfina, a heroína e, sobretudo a cocaína. 
Para parte dessas elites seria um símbolo de sofisticação francesa, dos salões repletos de intelectuais e dos finos cabarés de cortesãs luxuosas. Eram consumidos pelos "moços de boa família" e, não raro, pelas "mocinhas da melhor sociedade". Para outra parte, setores mais conservadores dessas classes abastadas, e para a imprensa esse consumo de drogas pelos jovens de elite causava indignação, reagiam fortemente ao ver seus filhos, sua jeunesse dorée praticando atos que eram associados à licenciosidade. Nos jornais e manuais da época os "vícios elegantes" eram tomados como o resultado indesejado da "modernidade", a "corrupção dos costumes", trazidos na bagagem de jovens ricos que adotaram o hábito nos centros da Europa ou nos contatos sexuais com prostitutas, acusadas de contribuírem decisivamente para a disseminação dos "vícios elegantes" entre os "bons moços" da juventude, como se verá adiante. (CARNEIRO, 1992, p. 6-7)

A expressão "vícios elegantes" indica que havia uma diferenciação na percepção do fenômeno do consumo de psicoativos, bem como, na percepção de quem eram os usuários, o que acabava por transformar-se numa diferenciação da forma com que o Estado e a sociedade lidavam com ele. De fato, a atitude de médicos e autoridades em relação aos casos de abusos de drogas poderia mudar significativamente a depender de quem era o usuário: os membros das elites econômicas muito raramente poderiam surgir em casos policiais envolvendo drogas, assim como os tratamentos de dependentes abastados eram extremamente discretos e reclusos como bem demonstra Benjamim Costallat em "O segredo dos sanatórios" de 1924. (BRETAS, 1997; CARNEIRO, 1992; RESENDE, 2006)

O mais paradigmático dos "vícios elegantes" foi, sem dúvidas, a cocaina. A literatura foi muito atenciosa quando o assunto era a cocaína, tendo merecido as reflexões de Lima 
Barreto, Álvaro Moreyra, Benjamim Costallat, João do Rio, Coelho Neto, Théo-Filho e até do sambista Sinhô, entre outros. (RESENDE, 2006) Esse alcaloide da folha de coca, isolado e nomeado na segunda metade do século XIX por Albert Niemann, foi logo produzido em larga escala pela indústria farmacêutica, a exemplo da poderosa alemã Bayer, e seu uso foi rapidamente difundido no mundo associado à euforia moderna e ao charme parisiense do "excesso", mas também aos perigos do submundo das grandes cidades.

Tomada como "panaceia universal" para todos os males nos fins do século XIX e exaltada com entusiasmo por Sigmund Freud, a cocaína passou a ser comercializada em farmácias e recomendada pelos médicos até ser alvo de interdições internacionais, devido a conflitos de interesses entre as grandes potencias capitalistas, ainda na primeira década do XX. (BASTOS, 1992; SCHEERER, 1993) No Brasil, foi das primeiras substâncias psicoativas proibidas, antes da maconha, ao lado do ópio e seus derivados, pelo Decreto n. 14.969 de 1921, cuja consequência principal foi o surgimento de um comércio ilegal e violento para continuar suprindo a demanda que não reduziu com a lei. (RESENDE, 2006)

Uma imagem desse consumo de cocaina pelas elites do Rio de Janeiro foi cantada por Sinhô em 1923:

Só um vício me traz

Cabisbaixa me faz

Reduz-me a pequenina

Quando na tenho à mão

A forte cocaína

Quando junto de mim

Ingerindo em porção

Sinto sã sensação

Alivia-me as dores

Deste meu coração 
Ai!...Ai!...

És a gota orvalina

Só tu és minha vida,

Só tu ó cocaína!

Mais que a flor purpurina

É o vício arrogante

De tomar cocaína

Sou capaz de roubar

Mesmo estrangular

Para o vício afogar

Nesse tóxico bravo

Que me há de findar.

(SINHÔ, 2006, p. 86-87)

Criação da "distinta atriz Celeste Reis" e dedicada a Roberto Marinho, futuro dono da Rede Globo, na época com 19 anos, a "canção-tango" se chama "A cocaína".

Sinhô, sambista dos primeiros tempos de sucesso do samba na indústria cultural, frequentou as festas e encontros da intelectualidade do início do século XX em São Paulo e no Rio de Janeiro, época que o samba, não sem conflitos e diferenças de apropriação, passava cada vez mais a significar para parte desse grupo um simbolo da identidade nacional. (ABREU, 2010; CUNHA, 2001, 2008; GOMES, 2003; SOUZA, 2003) Na letra, ao mesmo tempo, a cocaína é um vício arrogante e a gota orvalina que alivia as dores do coração e provoca sã sensação. É o máximo, única, a flor purpurina, a própria vida. Mas também poderia ser um perigoso tóxico bravo e levar o usuário ao crime roubar, estrangular ou pior, à morte que me há de findar. Remédio para todos os males, símbolo de status e distinção, perigo que pode levar à morte, essa miríade de percepções fez a carreira da cocaína na história. 
Apesar dessa indiferença em relação ao consumo de maconha fora do mundo dos subalternos, que se transforma numa grande lacuna na história da sua presença na sociedade brasileira, a própria literatura proibicionista dos anos 1930 e 1940 demonstrou que ela foi percebida de maneiras diferentes pelos grupos sociais mais abastados de outras sociedades. Como exemplo, o uso entre as cortes reais na China e na Pérsia antes da era cristã, da bebida conhecida como nepenthes, típica das casas da elite grega na antiguidade e do "Clube dos haschischins" da elite intelectual parisiense no século XIX. (BARBOSA, 1958; CARDOSO, 1958b) Os literatos Assis Cintra e Olavo Bilac foram dos poucos olhos atentos a esse aspecto no Brasil.

O primeiro assinalou a sua presença na Corte de D. João VI. Cintra, numa biografia bastante picaresca da rainha Carlota Joaquina, conta que a "diamba" havia subido os degraus da realeza imperial com a rainha, que a teria usado com frequência como veneno para "despedir inimigos para o inferno". (PERES, 1958, p. 69) A singularidade na narrativa é sua origem ser apontada no Amazonas e não no Nordeste como seria algum tempo depois, o que pode indicar que realmente houvesse maconha dessa região na capital do Império ou pode ser uma associação genérica, ligada à representação da Amazônia como lugar onde predomina o elemento natural, as ervas, etc.

Apesar do tom manifestadamente jocoso e cômico da narrativa, visto que o escritor pretendia ridicularizar a rainha, não seria improvável que os nobres portugueses realmente tivessem contato com a droga. Como também não seria improvável que tivessem conhecido as suas possíveis propriedades venenosas na Europa. Além de ter o óleo de sua semente utilizado como combustível para a iluminação pública e a sua 
fibra utilizada para produzir papel, a Cannabis era extremamente explorada com finalidades têxteis na Europa. Sabe-se, por exemplo, que cordames e velas para embarcações que fizeram a expansão marítima portuguesa eram feitas de cânhamo, a fibra têxtil extraída do caule da planta. (CARNEIRO, 2002a; ESCOHOTADO, 2004; RUBIN, 1975) Dessa fibra também eram produzidos diversos tipos de tecidos provenientes de várias partes do continente. ${ }^{20}$ (DUPLESSIS, 2010) Essa atividade econômica era tão significativa na Europa que foi implantada pela Coroa Portuguesa no Rio Grande do Sul em 1783 uma fazenda para desenvolvê-la, a Real Feitoria do Linho Cânhamo, visando à produção e exportação da fibra para a Europa. (MENZ, 2005)

A literatura de fins do século XIX sinalizou com outra possibilidade que pode não ter sido apenas ficção. Olavo Bilac, num conto de 1894, evidencia um tipo de uso medicinal de preparados de maconha. Na narrativa a maconha é referida como Cannabis indica, nome hoje usado para se referir a outra espécie da planta, mas na época empregada às vezes para designar também a Cannabis sativa, já que ainda não se conhecia muito sobre a especificidade botânica do gênero Cannabis. Num "jantar de refinados", o jovem Jacques relata a sua experiência com um preparado da planta aos seus colegas entre baforadas de charutos, cálices de chartreuse verde e comentários sobre Baudelaire:

Foi há pouco tempo. Estava eu morrendo de tédio numa cidade do Norte. Toda a solidão daquelas ruas muito direitas, muito largas e muito vazias me havia entrado na alma. Como eu me aborrecia, meus amigos! E imaginem

20 Entre estes se destacavam o Batista, o Brim, o lenço de Cholet e o Zingas. Poderiam ser de cânhamo apenas ou dessa fibra mesclada ao linho ou ao algodão. Eram produzidos, em geral, na França, mas também em Flandres e na Bretanha francesa. 
que, por esse tempo, sofria eu de uma singular excitação nervosa, que me fazia ficar semanas inteiras sem dormir, com o corpo quebrado, todo o organismo vibrando dolorosamente ao menor choque, à menor contrariedade, à menor emoção [...] Um dia, um médico meu amigo aconselhou-me o uso do ópio.

Protestei que seria inútil: a morfina, o láudano, tinham sido impotentes, deixavam-me o corpo despedaçado [...]. Ele, então, receitou-me um novo preparado...

Não conhecem vocês, com certeza: é o tanato de canabina. A canabina é o alcalóide que se extrai do haxixe, da Cannabis indica [...]. (BILAC, 2006, p. 29-30, grifo nosso)

De início, se percebe a relação, que seria consolidada futuramente no discurso médico, entre a Cannabis e as regiões Norte e Nordeste do Brasil: a personagem teve contato com a substância derivada da planta quando se encontrava "numa cidade do Norte". Vale lembrar que em fins do século XIX ainda não existiam oficialmente as duas regiões de forma independente uma da outra, sendo o "norte" todo o território que ia da Bahia ao Amazonas.

O que se destaca neste trecho da narrativa é a presença do médico, receitando o derivado da maconha como medicamento para a "excitação nervosa" do jovem abastado Jacques. E o "tanato de canabina" não foi a primeira opção sugerida pelo doutor, antes the aconselhou o "uso do ópio". O jovem rico nos deixa ver que esse tipo de tratamento médico à base de substâncias psicoativas poderia ser ainda mais comum, pois já havia tentado a morfina e o láudano, mas "tinham sido impotentes" para resolver seu problema. Diante dos fracassos e dos protestos do rapaz, o doutor decide por um "novo preparado".

O nome do medicamento, "tanato de canabina", é sugestivo: "tanato" é uma expressão grega que significa "morte", tendo 
inclusive nomeado um dos deuses daquele panteão, Tânatos, irmão de Hipnos, deus do sono. Sendo a "canabina" um "alcalóide" extraído da planta, hoje mais conhecido como canabinol, o preparado em questão além de trazer a cura poderia levar à morte. Um título, então, bem íntimo do sentido que os gregos atribuíam à expressão phármakon, da qual derivou o fármaco, farmácia e farmacologia, ao mesmo tempo remédio e veneno. É ilustrativa desse aspecto a atitude do médico ao entregar o medicamento a Jacques: "O farmacêutico, solícito, recomendou-me com ares misteriosos que não tomasse, em caso algum, mais de duas pílulas". (BILAC, 2006, p. 30)

É nessa atmosfera de ambiguidade sobre a ação fisiológica do derivado de maconha que segue o relato do jovem:

Esperei a noite com uma ansiedade grande. Às dez horas tomei duas pílulas, deitei-me, e, abrindo um livro qualquer, chamei o sono. [...] Correra uma hora. Nenhum efeito. [...] Sorri, com desdém, do poder do narcótico, e engoli corajosamente mais três pílulas, e dali a um quarto de hora uma outra. [...] não sei se acharei palavras para lhes referir o que principiou então a passar-se em mim. [...] Foi uma coisa horrivel, sobre-humana, inenarrável, prolongada por toda a noite. Eu não dormia, mas não estava acordado. Dentro do meu corpo havia uma alma que sentia, que pensava; mas, como hei de eu explicar isso? Não era a minha verdadeira alma, porque essa eu a sentia fora de mim [...]. Depois, senti que acabara o desdobramento da minha personalidade. Estava outra vez com uma só alma. O corpo continuava a sofrer, sofrer indizivelmente. [...] Recapitulei toda a minha vida, de dia em dia, de hora em hora. [...] Foi então que dormi, sono bruto, sono de pedra, sono de morte, por dez horas a fio. (BILAC, 2006, p. 30-32)

E após a descrição da sua experiência com o preparado, complementa: 
O mais curioso, concluiu Jacques, depois de uma pequena pausa, é que o abalo produzido por essa noite no meu organismo foi tão forte, tão brutal, que me restituiu a saúde: equilibrou-me os nervos e livrou-me da insônia. De modo que a canabina me curou, não pelo bem, mas pelo mal que me fez [...]. (BILAC, 2006, p. 32)

Apesar da aterrorizante descrição da "viagem" feita pelo abastado moço, um dos seus amigos presentes ainda objeta: "Mas isso nada prova... Você sofreu assim, porque o excitante encontrou mal preparado o terreno em que devia operar". (BILAC, 2006, p. 30)

O jovem contrariou o conselho médico e excedeu bastante a dose: o preparado, adquirido como remédio, mostrou-lhe, então, seu lado de veneno, de morte, de "tanato". Ainda que o médico tenha lhe alertado, Jacques não possuía referenciais para uma dose ideal, assim como não os possuía para os efeitos: esperava que surgissem imediatamente e, como não sentia nenhum, teria decido avançar o estabelecido, o que o levou à superdosagem. Na narrativa, a personagem já havia experimentado outros psicoativos e também tido efeitos indesejados, ficava com o "corpo despedaçado". Depois de uma noite inteira a "sofrer indizivelmente", que o faz sentir um "desdobramento da personalidade", com uma alma dentro e outra fora do corpo, dormiu um "sono bruto", "sono de morte, por dez horas a fio".

Contudo, o preparado teria proporcionado também a cura do jovem, equilibrando os nervos e livrando-o da insônia. A ambiguidade fica por conta da sua conclusão: se o "tanato de canabina" the curou, foi pelo "mal", devido ao "abalo forte e brutal" produzido em seu organismo, e não pelo "bem". Essa perspectiva gera uma discordância entre os ricos rapazes, visto que na visão de um deles, o problema não está na substância, 
mas em quem a utiliza, com o "terreno", o organismo "mal preparado", e na forma que esse uso é feito.

Mesmo se a história de Jacques, Bilac conclui com um conselho do jovem para que os outros moços não experimentassem o "tanato de canabina", pode-se perceber a miriade de questões envolvendo a maconha naquele contexto: os médicos, que ainda ensaiavam o combate às drogas, nesse momento estimulavam o seu consumo com seus receituários; se a maconha e seus derivados ainda não eram condenados tão veementemente como viriam a ser algumas décadas adiante, já se apresentava certa tendência à reprovação do seu uso; e, por fim, dividia opiniões entre as elites, havendo aqueles que não a vissem enquanto um mal absoluto. Complexidade que deveria fazer parte dos circuitos sociais por onde Olavo Bilac se movia e encontrava inspiração para sua literatura.

Como dito linhas atrás, alguns elementos da narrativa de 1894 não deixam de possuir um aporte na realidade do período. No famoso "Formulário e Guia médico" de Pedro Napoleão Chernoviz, de 1888, está indicada a maconha para fins terapêuticos, referida como "haschich" "haxixe":

Contra a bronchite chronica das crianças [...], fumam-se cigarrilhas Grimault na asthma, na tísica laryngea [...]. Debaixo de sua influência o espírito tem uma tendência às idéias risonhas. Um dos seus efeitos mais ordinários é provocar gargalhadas [...]. Mas os indivíduos que fazem uso contínuo do haschich vivem num estado de marasmo e imbecilidade. (CARLINI, 2006, p. 315)

As referidas "cigarrilhas Grimault" eram os mesmos "cigarros Índios, Cannabis indica", como constava em anúncio de jornal em 1905: 
Figura 4 - Anúncio de jornal de 1905 oferecendo cigarros de maconha para ricos

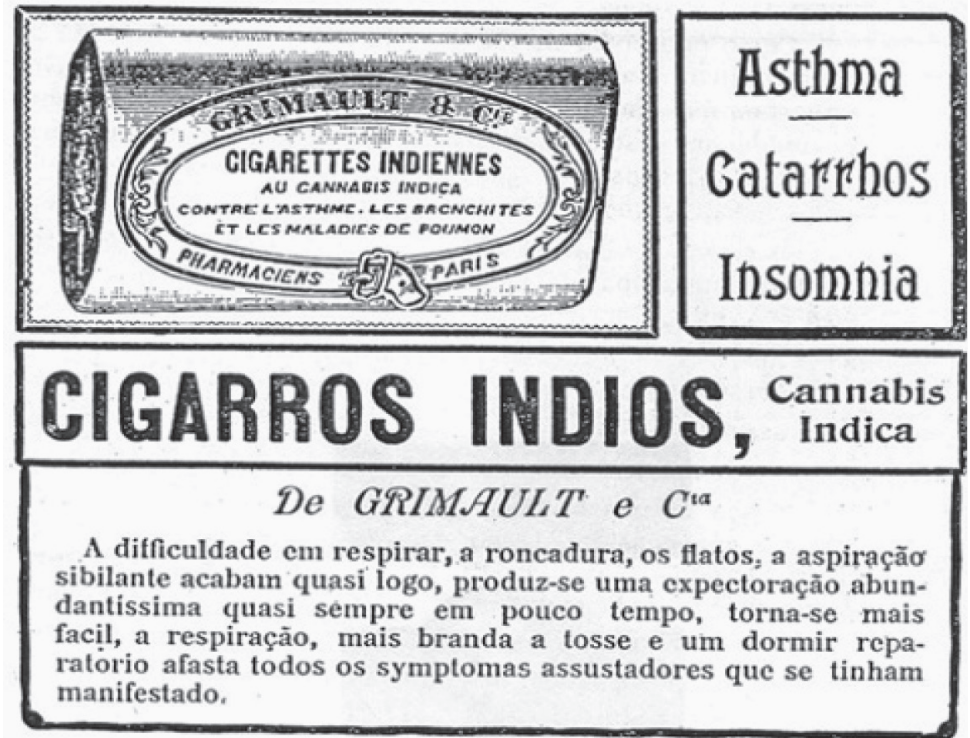

Fonte: Carlini (2006, p. 316).

Segundo o "Guia médico" do doutor Chernoviz, a Cannabis era usada nos fins do século XIX como medicamento contra problemas respiratórios, inclusive de crianças. O médico ainda tece algumas considerações acerca dos seus efeitos psicoativos, demonstrando certa ambiguidade a sua opinião. Por um lado, provocava comumente "ideias risonhas" e "gargalhadas". Por outro, o "uso contínuo" levaria o indivíduo ao "marasmo" e à "imbecilidade". Essa última consideração de Chernoviz parece aproximar os efeitos da maconha aos do ópio, operação já realizada pelo discurso médico francês e que viria a ser incorporada ao brasileiro no século XX.

As "cigarrilhas Grimault", citadas pelo médico em 1888, ainda eram comercializadas quase vinte anos depois e indica- 
das para o tratamento da insônia, o mal que atormentava o jovem Jacques do conto de Bilac. Eram produzidas por laboratório farmacêutico, recebendo marca francesa e embalagem refinada, como se pode ver na imagem acima, para seduzir e agradar os gostos de uma clientela abastada. No anúncio vê-se a grande exaltação das suas propriedades terapêuticas: "asma", "catarros", "roncos" e "flatos" com seu uso acabariam "quase logo", tornando a respiração "mais fácil", a tosse "mais branda" e provocando um sono "reparatório" capaz de afastar "todos os sintomas assustadores" de antes. Alguma semelhança com a história do jovem abastado Jacques?

Parece que a maconha no Brasil não conviveu apenas com os indivíduos considerados "sem cultura" da "mais baixa escala social" como defendiam os médicos no século XX. Assim como parece também que esses, os criadores do discurso que embasou a criminalização da maconha no país, se esforçaram com visivel sucesso para ocultar essa relação. Conseguiram até ocultar a sua própria relação, de cura e "tanato", com a Cannabis.

Por isso, são extremamente reduzidos os casos conhecidos, se comparados àqueles envolvendo as classes subalternas. Porém, alguns casos dispersos provam que, de vez em quando, a mocidade abastada experimentava da "maldita".

Foi o que noticiou o Diário de Itabuna, no sul da Bahia, em 1958. O caso, no entanto, ocorreu em São Paulo:

O quadro é o mais deprimente de quantos temos conhecimento. Moços paulistas, da melhor sociedade, entregues ao vício da maconha, constituíram-se no Clube dos 50, que tem por fim danificar a propriedade alheia, causar prejuizos grandes aos seus semelhantes. (NOSSO, 1958, p. 1) 
Após noticiar o ocorrido em outro estado, prossegue em tom revelador e agressivo:

Estamos desconfiados de atividades perniciosas de alguns elementos que se acham nesta cidade, bem instalados $[\ldots]$ É gente estranha ao nosso meio [...].

Não permitiremos, de maneira alguma, que seja essa desgraça implantada em nosso meio. Nossa mocidade, briosa como sempre, digna e decente, respeitadora das nossas mais caras tradições, deve estar alerta e colaborar conosco na investigação dessas atividades.

Uma coisa podemos dizer: Se se positivarem os receios que temos, saibam esses elementos que agiremos de qualquer maneira, que nossa reação será brusca e poderemos nos exceder, porque um cancro desses exige reação violenta. Saiam de Itabuna se seus intentos são esses. Maconha não entrará em nossa terra. (NOSSO, 1958, p. 1)

O jornal do sul da Bahia indica, num paralelo revelador, que não eram pobres, como de costume, os suspeitos das tais "atividades perniciosas". Primeiro, relata um caso, atípico em jornais, de "moços paulistas da melhor sociedade" envolvidos num escândalo público de prisão em flagrante por uso de maconha. Depois levanta a suspeita de que "elementos bem instalados" na cidade, ou seja, também "moços da melhor sociedade", vindos de fora, estariam fazendo uso clandestino da erva. Evocando, então, os brios da mocidade, avisa aos "elementos suspeitos" que as autoridades reagirão violentamente para exterminar essa "desgraça", esse "cancro" que era, em sua opinião, a maconha. ${ }^{21}$

21 A década de 1950 foi de insistentes ações do poder público e de intensa campanha da imprensa em prol da "modernização" de Itabuna, por conta das comemorações do seu centenário, o que resultou em diversas frentes de atuação desses agentes com intuito reformador como o espaço urbano, 
Sonhos da diamba

Figura 5 - Os "bons moços paulistas" que fumavam maconha

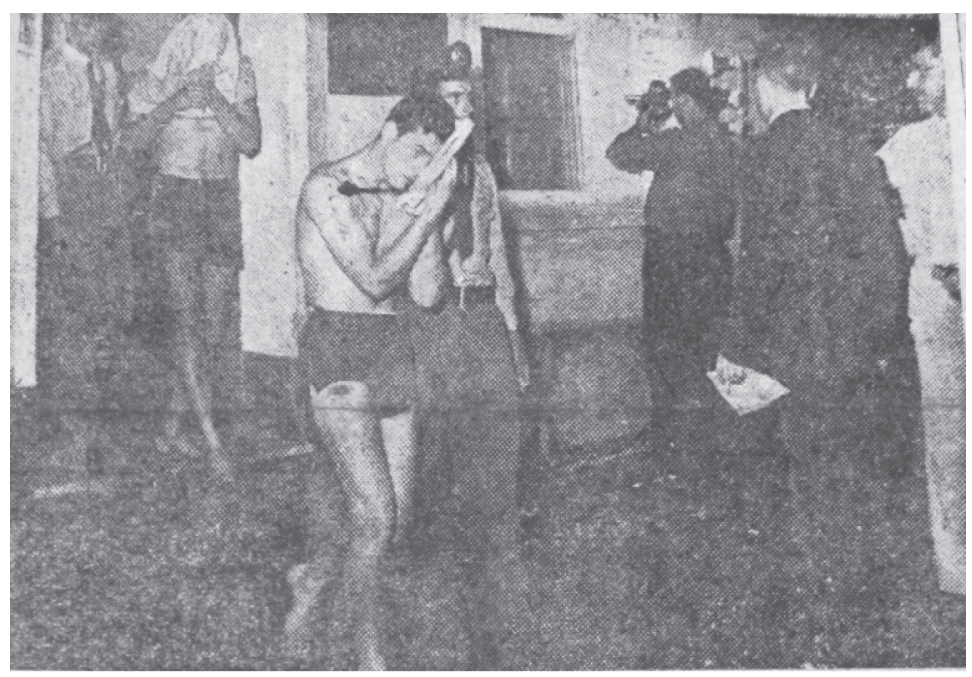

Fonte: NOSSO (1958, p. 1).

A outra referência trata sobre Salvador. O folclorista Alceu Maynard Araújo percorreu o interior do Nordeste na década de 1950 colhendo informações para compor o seu estudo sobre práticas não oficiais de cura, que foi publicado sob o título de Medicina Rústica. Ao chegar a Piaçabuçu, interior de Alagoas, o estudioso conversou com o prefeito da cidade sobre usos tradicionais de maconha e reproduziu suas palavras:

Eu me lembro que em Salvador, quando estudava, os rapazes se reuniam para fumar maconha, preparavam por assim dizer o ambiente, eu vejo agora esta gente, estes matutos fumando e nada sentem. Pode crer que a maconha é um mito que precisamos acabar com ele. Já ouvi um professor falar a esse respeito. (ARAÚJO, 1979, p. 259, grifo nosso)

o comércio popular, os costumes da população subalterna etc. (SOUSA, 2010) 
O dr. Antônio Machado Lobo, prefeito da cidade, era "farmacêutico diplomado" pela Faculdade de Medicina da Bahia, instituição fundamental para a consolidação do proibicionismo da maconha no Brasil, formando autoridades no assunto como João Rodrigues Dória e João Ignácio de Mendonça, já conhecidos nossos. Portanto, os corredores e salas de aula da FMB eram lugares onde se ouviria "um professor falar a esse respeito".

O que é bastante peculiar na sua fala é o fato de sugerir que jovens de classes elevadas em Salvador, provavelmente estudantes da faculdade, "se reuniam para fumar maconha". No seu espanto em relação aos efeitos da maconha nos comportamentos dos usuários da cidade de Piaçabuçu, contraditórios em relação ao modelo de "maconheiro" que ele deve ter ouvido falar diversas vezes naquela instituição, o doutor deixa escapar informações sobre esse consumo fora das classes subalternas na capital. Isso fica claro na dicotomia dos termos empregados pelo prefeito: "os rapazes" de um lado e "essa gente", "esses matutos", de outro. Não resta dúvida de que se trata de classes sociais diferentes.

Os "rapazes" "preparavam o ambiente", ciosos dos efeitos da erva, diante de tantas informações assustadoras sobre o assunto que recebiam na FMB e na falta de referenciais de uso não problemático, enquanto que aquela "gente matuta" do sertão "nada sentia". Nesse ponto, o doutor foi mais um cientista que percebeu que os usuários não eram todos iguais. Porém, não deixa de ser impressionante imaginar que, exatamente, aqueles que deveriam ser os grandes opositores do uso da droga parecem ser também os usuários: jovens da "melhor sociedade", quiçá estudantes numa das instituições que mais combatia esse consumo. Será esse um dos motivos implícitos no interesse do doutor em acabar com o "mito da maconha"? 
Saindo agora do universo masculino para ver o que se dizia das mulheres quando estas se relacionavam com a maconha. O proibicionismo da maconha no Brasil parece não ter dispensado grande atenção às questões de gênero quando o assunto eram os seus usos criminalizados, contudo não deixou de tocar neste ponto. Exemplo disso está no início da investida médica condenatória com Assis Iglésias em 1918. O sanitarista acusa calorosamente que o hábito de fumar maconha estava passando dos casebres da "gente rude" para os quartos das "prostitutas". A seguir, profetizava que por meio do contato com essas mulheres "os moços elegantes se embriagarão com a diamba" e, levando o hábito para as suas irmãs, "o vício terrivel passará a fazer parte da moda”. (IGLÉSIAS, 1958, p. 21)

Nesse clamor profilático, o doutor vê a mulher com ambiguidade: seria, na figura das prostitutas, um agente ativo na disseminação do que ele considera "vício", e um sujeito passivo, dessa vez as "moças elegantes", que o receberia naturalmente, sendo inevitável o abuso e a degradação. As vítimas seriam os "moços elegantes" e as suas irmãs, enquanto que o papel de vilão ficou para as prostitutas. Nesse ponto, Iglésias faz eco ao contexto histórico de reformas urbanas, remodelação dos espaços e dos mecanismos de controle social, eugenia e crescente medicalização da sociedade. Nesse bojo, um dos grupos citadinos mais visados pelas intervenções de "limpeza social" dos poderes públicos foram as prostitutas.

No início da República as prostitutas eram vistas de diferentes maneiras pela sociedade abastada. Poderiam ser associadas à boemia e aos comportamentos sexuais considerados desviantes, tornando-se alvo de intervenções do poder público, sobretudo nos momentos de reforma urbana e seu corolário de "limpeza moral", processo antigo, mas que se atualizava frequentemente para dar conta das transformações da sociedade. 
Mas também eram desejadas e muito procuradas, conformando no imaginário burguês parte fundamental de um estilo de vida cosmopolita e dos ritos de iniciação sexual dos rapazes. (CARNEIRO, 1992; SCHETTINI, 2006)

Médicos, autoridades e as "boas famílias" apontavam as prostitutas, grupo bastante heterogêneo, tanto culturalmente quanto na atividade que exerciam, como "viciadas" e traficantes, assim como viam os cabarés e "casas de tolerância" como terreno fértil para a propagação dos "vícios". Na figura abaixo, por exemplo, se vê a clara associação entre prostituta, sexualidade e drogas nos Estados Unidos.

Figura 6 - "Cocaína Lil", protagonista de uma canção popular de jazz dos anos 1930 nos EUA

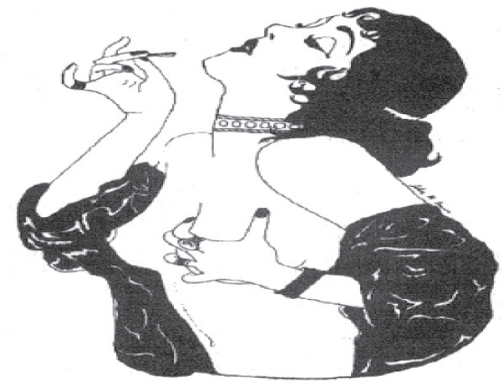

Fonte: Carneiro (2008, p. 90).

Sendo assim, a mulher já entra nas considerações proibicionistas em relação à maconha com esse duplo caráter, mas convergindo para o mesmo ponto: a mulher contribuía decisivamente para a propagação do "vício" que passava a ser combatido pela medicina.

Na década de 1930 o engenheiro agrônomo e ativo militante do proibicionismo da maconha Antonio de P. Leonardo Pereira também faria uma reflexão, associando uma visão 
Sonhos da diamba

patriarcal da mulher com um dos diversos discursos sobre o sertão naquele contexto:

Quando no rico sertão nortista, se encontra a sertaneja, bela moça, de carnes rígidas desafiando a natureza na sua pujança de reprodução, mas trazendo nos olhos pretos, que ferem como setas, a melancolia, a dor do coração de quem foi renegada, é 'na taça daquele haschisch das ébrias do amor', que a desgraçada encontra o calor de sua paixão. (PEREIRA, A., 1958, p. 50)

A maconha aí está referida como "haschisch", por meio de uma citação de Camilo Castelo Branco.

A mulher "sertaneja" é vista de forma naturalizada quase numa simbiose com o meio ambiente através de uma narrativa que evidencia elementos que seriam inatos. Por um lado, é forte, de "carnes rígidas", por outro, é "renegada", a "desgraçada" e fraca, que busca na droga o alento para as dores da sua condição. A família sertaneja é entendida como um "desafio à natureza", fruto da própria constituição biológica da mulher. Emerge também um discurso naturalista sobre o sertão, concomitantemente "rico", melancólico e "renegado". Nessa imagem, a mulher continua a ser vista como um ser frágil, facilmente vitimado e naturalmente tendente aos "vícios". Por essa miríade de questões, ainda contribuiria para a propagação do "maconhismo".

No início da década de 1950, Décio Parreiras acrescenta mais uma conclusão a que chegaram os médicos sobre essa questão. Analisando dados levantados por João Mendonça na Bahia, Parreiras (1958, p. 264) nos diz:

Na observação baiana, as mulheres são menos aprecidoras da diamba e, em 100 padecentes, havia 1 mulher, e esta era meretriz. As mulheres são mais pacíficas que o homem; de maior domesticidade; com menores conflitos sociais; maior religiosidade e ciclotimia maior". O doutor 
compartilhava da opinião da CNFE de que seria "[...] decisiva a constituição individual, no desenvolvimento do canabismo. (PARREIRAS, 1958, p. 263)

O médico afirma que a mulher tem características inatas e universais que determinam o seu menor interesse pelo consumo psicoativo da maconha. São naturalmente "mais pacíficas", mais "domesticáveis" e "religiosas", além de que seus "conflitos sociais" seriam "menores" que os masculinos. Não nos diz nada sobre outros usos entre as mulheres, como o medicinal popular ou o religioso. Dessa forma, mais uma vez se justifica as diferenças entre os usos da maconha feitos por homens e mulheres pela via do inato, do natural. A desviante dessa pretensa norma de um padrão comportamental seria alguém já considerada "viciada", era uma "meretriz" nos diz Parreiras, reproduzindo a conhecida e antiga associação entre prostituição e maconha.

Essa visão dicotômica da mulher usuária de maconha, na qual esta é ao mesmo tempo vista como agente ativo e passivo na reprodução do hábito, como sujeito forte do interior do Brasil, mas fraquejando pelos castigos do meio e como inatamente dóceis, mas propensas aos vícios, fornece um argumento que naturaliza diferenças histórico-culturais. As mulheres deveriam continuar vigiadas, para que não concorressem consciente ou inconscientemente para a existência do uso. Em todo caso, estaria agindo de forma natural: a maioria não usuária psicoativa, seguindo o padrão natural, as desviantes, se afastando dele, mas evidenciando que já eram naturalmente fracas e viciadas.

Foi seguindo essa ótica que $A$ Tarde noticiou, em 8 de abril de 1951, o envolvimento de duas garotas numa "quadrilha de menores". O líder do grupo seria o "jovem Silas Portugal" e o mais ativo dos membros era "Joãozinho, o terror". Juntos com outros cinco ou seis jovens teriam sido os responsáveis 
por assaltos como o da "Joalheria Brilhante" e da loja de discos "Radiolar", além do assassinato do industrial paulista Horácio Pires em Salvador. Segundo a matéria, a turma "era composta, na sua maioria, de maconheiros", sendo um jovem que atendia pelo nome de "Tavinho, irmão do subdelegado Moreira", que atuava no bairro do Uruguai, o "vendedor da maconha". (QUADRILHA, 1961, p. 5) Apesar da enxurrada de acusações, não foram encontradas as falas dos acusados.

Sobre as mulheres envolvidas com a quadrilha e a maconha, diz o jornal:

DUAS GAROTAS ENVOLVIDAS - Além dos nomes já conhecidos pela polícia, há ainda duas jovens que fornecem maconha para a quadrilha e 'pitam' a erva: Cilza e Lícia, esta última, uma jovem de pouco mais de quinze anos, morena, envolvida há tempos num caso no Aeroclube, com outras garotas de Santo Antônio, indo o fato acabar na polícia. Lícia, na época, ia ser internada, porém seguiu para Alagoinhas, onde ficou em companhia de seus familiares, retornando agora para enveredar no caminho do crime. (QUADRILHA, 1961, p. 5)

A polícia já estaria no "encalço das garotas", pois sabiam que as duas residiam "numa pensão do Areal de Cima".

A matéria acusa as garotas Cilza e Lícia de serem traficantes e consumidoras de maconha. Dessa forma, a matéria conferiu as jovens um papel ativo na propagação do "vício", como propunham os médicos, pois elas eram as "fornecedoras" da maconha para a "quadrilha". E ao mesmo tempo em que fornecem, "pitam a erva".

A seguir, o foco recai sobre uma jovem chamada Lícia, o exemplo de desequilíbrio feminino. Com seus "pouco mais de quinze anos" já tinha o nome envolvido em crimes nos jornais e havia sido sentenciada ao internamento. Ela teria recusado a "companhia dos familiares" no interior, preferindo voltar à 
capital para "enveredar no crime". Ao rejeitar o seu "lugar natural", o seio da família, e optar por morarem juntas "numa pensão" é enquadrada no perfil da mulher possuidora de caracteres inatos que a tornam vítima passiva da droga e tendente ao crime.

O outro caso envolvendo uma mulher nos usos proibidos da maconha também se deu em Salvador, mas no ano anterior, 1960. Cleyde Maranhão foi presa juntamente com Flaudísio Lopes no dia 18 de agosto no posto policial de Campinas de Pirajá, acusados de transportar um saco de maconha em um caminhão. (ARQUIVO PÚBLICO DO ESTADO DA BAHIA, 1960) A Tarde publicou uma pequena nota sobre o caso, no dia seguinte, afirmando ser Cleyde bailarina e presa por envolvimento num caso de apreensão de "um saco da erva maldita". O mandado de prisão foi expedido pelo juiz Durval Moncôrvo da $2^{\text {a }}$ Vara Crime da capital e cumprido agente Clovis Barbosa, “preposto da Delegacia de Jogos e Costumes". (PRESA, 1960, p. 8)

O advogado João Maxiliano impetrou, então, pedido de habeas corpus em favor de Cleyde no Tribunal de Justiça, no qual tecia diversas críticas à decisão judicial e à ação da polícia e solicitava o seu "indispensável alvará de soltura". O pedido argumentou que a moça era "apenas uma passageira do veículo" e não tinha conhecimento do transporte da droga. Sendo assim, estaria sofrendo uma "coação ilegal" e injustificada, posto que destituída de provas. (ARQUIVO PÚBLICO DO ESTADO DA BAHIA, 1960, p. 2-4) O juiz da $2^{\text {a }}$ Vara, Durval Moncôrvo, então, oficia aos desembargadores e emite o seu parecer sobre o caso: a "jovem de vida fácil" empregou meios para impossibilitar a descoberta e interceptar a apreensão da "erva maldita", ocultou a "erva do diabo", "encheu-se de rebeldia" contra a diligência policial e aderiu aos "escusos e ilícitos interesses" 
de Flaudísio, "quem para ela não era mais do que um simples freguês do amor vadio". (ARQUIVO PÚBLICO DO ESTADO DA BAHIA, 1960, p. 10-11) Em acórdão, os desembargadores resolvem indeferir o pedido de habeas corpus e mantiveram Cleyde detida.

Importante aqui é analisar os argumentos do juiz, pelo visto, mais decisivos para a decisão do tribunal, que os do advogado da moça. Na opinião do magistrado, a mesma do promotor, não havia dúvidas da culpa de Cleyde no caso, sendo-lhe justa a prisão preventiva. Embasava sua certeza considerando que a jovem atuou ativamente para atrapalhar a investigação: ocultou a droga, foi rebelde e associou-se aos atos ilegais do amante. Mas este seria um mero "freguês do amor vadio", pois era uma "jovem de vida fácil". Como Cleyde se mostrava muito distante do padrão de comportamento pacífico, domesticado e religioso que acreditavam os especialistas ser natural da mulher, é considerada uma prostituta, e estas possuíam, em sua ótica, uma tendência natural para os vícios. Mais uma vez se recorre à imagem da mulher como a parte ativa da propagação do hábito de fumar maconha e dessa vez por meio da personagem social considerada a mais representativa desse comportamento.

Infelizmente, não existem as explicações das duas acusadas no documento, o que poderia nos esclarecer diversas questões de cada caso, ainda que limitadas pela fala dos acusadores. Na verdade, foi extremamente restrito o número de fontes envolvendo mulheres em casos relacionados com a maconha. Esses dois acima discutidos formam quase a totalidade. Porém, somente isso não autoriza crer na versão proibicionista de que a mulher consumisse menos a maconha que o homem, devido a caracteres comportamentais inatos. 
Pode ser que as mulheres tivessem outras formas de contato mais recorrentes com a planta, a exemplo de usos medicinais nas diversas artes de cura não oficiais da população subalterna, enquanto a polícia e a imprensa dispensavam mais atenção ao uso psicoativo. O que também não elimina por completo a possibilidade de que fossem usuárias psicoativas e possuíssem outros padrões de uso. De qualquer sorte, tais questões vão depender de pesquisas específicas sobre o tema.

Sem dúvidas, a preferência das autoridades e da imprensa quando o assunto tinha maconha era pelos "vagabundos de oficio", os transgressores da ordem e da moral pública. A literatura médica que fundamentou a repressão proibicionista da maconha deu nomenclatura própria aos malandros da Bahia, utilizando expressão famosa na pena de Jorge Amado: "capitães de areia". Seus equivalentes em Pernambuco eram os "maloqueiros" e em Sergipe os "ratos cinzentos". (LUCENA, 1958; MORENO, 1958) No citado relatório produzido pelo dr. Parreiras (1958, p. 251) em 1949 pode-se encontrar elencados dezenas de nomes de "grandes traficantes e grandes fumadores" de maconha na Bahia tais como "Peixe", "Tabaréu", "Paulo Carão", "Catiá", "Neguinho", "Aranha Preta", "Bigode de catumba", "Urucubaca", "Camelinho", "Biá Bolinha", "Caboclo Isidoro", "Demarré", "Baixote”, "Buck Jones", "Ararão", "Negro Alfredo", "Preto de Mola", "Barrigão" e "Mão de seda".

A década de 1950 em Salvador era tributária de processos históricos mais distantes. Como foi visto no capítulo anterior, o estado no Brasil, no período pós-1930, levou a cabo uma expressiva reorientação dos mecanismos de controle social, para adequá-los às novas situações e sujeitos trazidos pelas profundas mudanças que o país vivia, e desenvolveu uma ampla politica cultural, apropriada de diferentes formas pelas 
diferentes grupos e indivíduos, com vistas a legitimar seus arranjos institucionais.

Foi significativo do primeiro aspecto, como foi visto, o tratamento dado ao direito criminal pelo Estado, primeiro sistematizando a matéria com o Decreto $n .^{\circ} 22.213$ de 14 de dezembro de 1932, a Consolidação das Leis Penais, e depois instituindo uma nova racionalidade jurídico-penal com o Decreto-Lei n. 2.848 de 7 de dezembro de 1940, o segundo Código Penal do período republicano. (ROLIM, 2010) Não é demais lembrar que o primeiro governo Vargas foi um divisor de águas da criminalização das drogas no Brasil, editando normas cada vez mais abrangentes, ratificando tratados internacionais e criando órgãos de fiscalização, repressão e educação contra os "entorpecentes" no país.

$\mathrm{Na}$ Bahia não foi diferente. Viu-se que órgãos como o Instituto de Investigação Criminal, criado em 1938, e o Museu de Criminologia, em 1943, além de eventos importantes como a I Semana do Urbanismo de Salvador, em 1935, atestam como se intensificavam as preocupações dos poderes instituídos com o espaço urbano e a segurança pública na capital. (UZÊDA, 2006) Em relação à proibição do consumo de drogas, o período possui notória centralidade: foi criada a Cefe, realizou-se o Convênio Interestadual da Maconha e houve duas visitas de inspeção no estado, realizadas pela CNFE.

Imprensa, Estado, comerciantes e intelectuais passavam a aderir à ideia de um potencial turístico de Salvador, na época, rota de passagem dos cruzeiros europeus e norte-americanos que seguiam para o Rio de Janeiro. Mas a cidade era definida como em tudo contrária a esse ideal e antigos problemas eram evocados. A população ainda era acusada de ser excessivamente barulhenta, lasciva e dada aos vícios, além de composta de desocupados e vadios, potenciais criminosos na mentalidade 
penal da época. As ruas eram consideradas estreitas, sujas, mal iluminadas e inseguras, o que aliado com a arquitetura colonial desgastada pelo tempo incomodava bastante as elites econômicas. (LIXO, 1958)

$\mathrm{Na}$ cabeça dessa classe, juntavam-se os temores do imenso contingente heterogêneo de subalternos, a constatação diária da grande propensão que estes tinham para a rebeldia e a migração para a capital de sertanejos da Bahia e de outros estados, crescente ao longo dessas décadas, formando o cenário que consideravam perfeito para a maconha, tomada como provocadora de crimes e geradora de loucos degenerados, se transformar num "problema social".

Na questão do controle social, com ênfase na repressão à criminalidade, o aparato policial da capital nos anos 1950 foi aquele montado nessas duas décadas precedentes e contava com a Guarda Civil, a Guarda Noturna, a Polícia Militar e a Polícia Judiciária, operando em três circunscrições policiais que esquadrinhavam a cidade em doze distritos, centradas nas três delegacias correspondentes às respectivas circunscrições além da Delegacia Auxiliar e de duas especializadas, a Delegacia de Jogos e Costumes e a Delegacia de Furtos e Roubos. (UZÊDA, 2006)

Os intelectuais, os políticos e as autoridades passaram a década buscando atualizar conhecimentos e tecnologias de repressão ao crime e gestão das populações urbanas, como demonstra a realização do III Congresso Brasileiro de Medicina Social e Criminologia em Salvador no ano de 1958, com a participação de médicos do exterior e do dr. Garcia Moreno, da Cefe de Sergipe, conhecedor do problema da maconha. Dois dos maiores "pontos de confluência" da malandragem soteropolitana nos meados do século XX materializavam esse quadro aterrorizante: a Rua da Ajuda e a Rua do Tesouro. Com suas 
“cenas dignas dos filmes de James Dean", essas artérias bem no centro da cidade reuniam tudo que o poder público buscava exorcizar, e pelo visto sem sucesso, havia décadas da vida popular: a boemia, a bebida, a maconha, o meretrício e o jogo.

A Rua da Ajuda, que se chamava também Padre Vieira, já havia mudado de nome nas crônicas policiais: era a "rua do crime" ou, mais eloquentemente, a "Esquina do pecado". Significativa a presença da palavra "pecado", empregada no lugar de crime, denotando, com a referência religiosa, a dimensão moral da questão da definição da criminalidade. Nas palavras de $A$ Tarde, a rua era o

[...] ponto de confluência de indivíduos de toda espécie, lá vivendo em promiscuidade absoluta, desordeiros e boêmios, mundanas e beberrões, maconheiros e agiotas, particularmente estes, que explorando os gastos excessivos de todos os que ali se reúnem, emprestam dinheiro a altos juros, construindo fortuna fácil. [...].

É a Ajuda, portanto, a artéria principal do 'bas-fond' na Bahia, o que, evidentemente, não deixa de ser lamentável. (ESQUINA, 1959, p. 4)

O repórter lamenta que uma das primeiras ruas de Salvador, uma "artéria" no centro da cidade, vizinha à famosa Rua Chile, tenha se transformado num "antro de maconheiros, decaídas, boêmios e agiotas". A rua cujo nome rendia homenagem à padroeira da primeira igreja de Salvador, Nossa Senhora da Ajuda, agora reunia indivíduos de "toda espécie" que se entregavam à jogatina e faziam a "fortuna fácil" dos agiotas, para desespero da imprensa. Dizia-se que ao cair da noite os "habitués" da Rua da Ajuda começavam a surgir, transformando-a numa "nova Monte Carlo" com "verdadeiros rios de dinheiro" correndo "por sobre as bancas verdes do vício e da perdição". (ESQUINA, 1959, p. 4) 
É claro que onde há pecado tem que estar o diabo, ou melhor, a "erva do diabo":

[...] Já não vai longe o dia em que, embriagado pela maconha, a terrivel erva que é vendida e fumada quase que livremente na Bahia, um viciado tentou assassinar um cidadão, só não o fazendo graças à intervenção de terceiros. Dois outros, também há pouco tempo e na mesmíssima artéria, já dominados pelo efeito diabólico da 'maldita', tentaram estrangular um motorista por eles contratado para uma corrida até a Pituba. (ESQUINA, 1959, p. 4)

Como numa "vida de boemia", dizia o noticiário, "[...] a bebida, a maconha, a mulher e o jogo não podem deixar de existir, senão estaria ela incompleta", o "efeito diabólico da maldita" lá se manifestava, ao que se atribuía a causa de assaltos e tentativas de homicídios. Nota-se a oposição entre "viciado" e "cidadão", totalmente em conformidade com as leis e o discurso médico da criminalização da maconha, nos quais qualquer usuário era necessariamente "viciado", sendo assim, passivel de "interdição civil" e "internação obrigatória". Já que não respondia mais por si, era um incapaz perante a lei, não seria cidadão.

A Rua da Ajuda foi a escola de "Bandeira", ex-jogador de futebol que por ali cresceu e na época infernizava a cabeça das autoridades, protagonizando assaltos de grande repercussão como o da elegante Joalheria David: “[...] nunca é demais lembrar que 'Bandeira' foi menino criado na chamada 'Esquina do Pecado' [...] Como ele, certamente, outros tantos hão de surgir”. (ESQUINA, 1959, p. 4) Se todos os meninos que moravam na Rua da Ajuda seriam ou não "gatunos" como "Bandeira", não importava. O determinismo social empregado pelo noticiário tomava a parte pelo todo e, como já visto antes, colocava sob suspeita qualquer um que tivesse o perfil, o que servia para justificar a repressão aos subalternos. Abaixo, detalhe de jornal com foto da famosa "Esquina do Pecado". 
Figura 7 - Rua da Ajuda no centro de Salvador pelas lentes de A Tarde

Esquina do pecado

NA RUA DA AJUDA, REALIZAM-SE OS MAIS ESTRANHOS NEGOCIOS

Antro de maconheiros, decaidas, boêmios e agiotas - O jôgo campeia ali



Fonte: ESQUINA (1959, p. 4).

Uma transversal da Rua da Ajuda era considerada seu complemento: a Rua do Tesouro. Como não deixaria de ser, essa também era "um inferno":

Ali costuma concentrar-se a escória da sociedade, num flagrante desafio às autoridades, [...] a travar, entre si, sérias lutas corporais, normalmente geradas por motivos fúteis, mas que têm nos entorpecentes os seus estimuladores.

Passam aí a noite, tendo o jogo de dados ou de baralho como complemento essencial às contravenções que praticam. (RUA, 1959, p. 4)

O entorpecente apontado pelas autoridades era a "maldita", fumada na "Escada de Cimara", ponto de encontro de "conhecidos maconheiros". Como de praxe, a imprensa via nesses lugares apenas confusão, jogo, vício e contravenção. Os desen- 
tendimentos e conflitos entre as pessoas que frequentavam a Rua do Tesouro, então, só poderiam ser "por motivos fúteis" e ter os "entorpecentes" como "estimuladores".

Vizinho ao Banco Hipotecário Lar Brasileiro funcionava o snooker Rex, atraindo pessoas para jogar bilhar ou jogar no bicho. Mas o Rex foi fechado e em seu lugar deveria ser instalada uma fábrica. Muito mais apropriado como considerava e festejava a imprensa, já que o trabalho era considerado um poderoso regenerador de criminosos, malandros e decaídas.

Havia ainda outra "casa de tavolagem" que horrorizava a imprensa e as "pessoas de responsabilidade", o snooker Abel. Em Abel se podia jogar durante o dia e se distrair à noite no dancing instalado no "seu andar superior". A imprensa também pretendia transformar o Abel numa fábrica, por isso o acusava de abrigar "malandros e desordeiros, jogadores e agiotas, mundanas e maconheiros", mas não se sabe se isso ocorreu. Incomodava também o fato de tudo isso se realizar na esquina da casa de Ruy Barbosa, tão "visitada por altas personalidades", e exigia-se "medida imediata da polícia" para "limpá-la" da "claque" que a imprensa afirmava lá viver. (RUA, 1959, p. 4) Abaixo, foto da Rua do Tesouro, inseparável complemento da Rua da Ajuda.

Figura 8 - Rua do Tesouro e seu famigerado "snooker" Rex

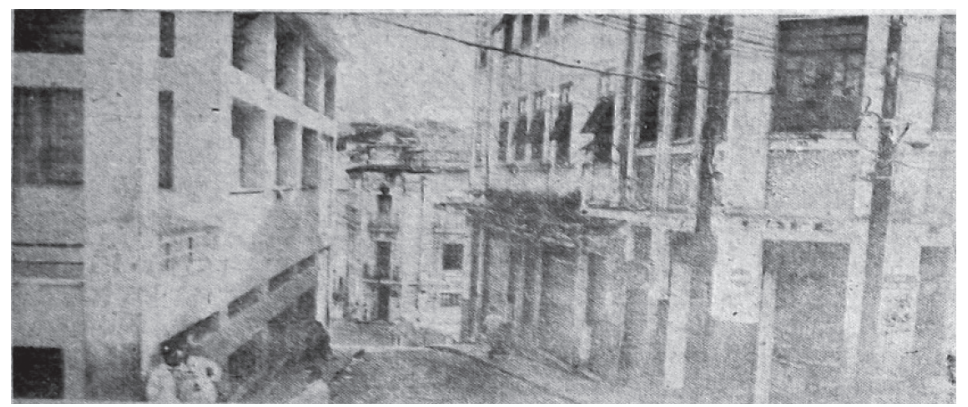

Fonte: RUA (1959, p. 4). 
Alguns frequentadores assíduos das ruas da Ajuda e do Tesouro se notabilizaram nas colunas policiais da cidade como "dr. Zumaêda", "Jandaia", Milton, Estevão e "Zé macaco", o "grupo da maconha". Em 1957 Zé foi preso pelo guarda 829, acusado de assaltar "à mão armada" no Mercado Modelo, provocando a ira do grupo. (PRESO, 1957, p. 3) Os colegas de "Zé macaco", apontado como chefe do grupo, entraram em conflito com o referido guarda numa madrugada de agosto, alguns dias depois da sua prisão e acabaram presos na Rua das Verônicas.

Mas ele sairia da cadeia para no ano seguinte voltar às páginas policiais, dessa vez, acusado de tentativa de assassinato. Diz a matéria: "Sob o efeito da maconha três indivíduos quase assassinam um motorista na Boca do Rio". (REEDIÇÃO, 1958, p. 7) Segundo o periódico, "Zé macaco", "Sergipinho" e Arlindo tomaram um táxi na Rua da Ajuda e após passarem de Amaralina se desentenderam com o motorista, resultando em briga e nos gritos de socorro desse, de nome Vadinho. "Zé macaco" teria sido o único a conseguir escapar do cerco policial enquanto os outros dois foram encaminhados para a Delegacia Auxiliar. Então, conclui o periódico:

Todos eles, segundo apuramos na referida delegacia, se encontravam sob o efeito da maconha, a terrivel herva (sic) que tantos crimes têm provocado no Brasil. Hoje, os maconheiros, depois de breve período, voltaram a fazer seu ponto de ação na Ajuda, onde, aliás, se encontravam os três viciados autores da agressão contra o motorista Vadinho. (REEDIÇÃO, 1958, p. 7)

A reportagem segue as linhas gerais do discurso contra a maconha, buscando encontrar nos seus efeitos psicoativos a causa do comportamento violento, aparentemente, desprovido de qualquer motivo e a mola propulsora do crime. Esse mesmo ocorrido foi mencionado na matéria sobre a Rua da Ajuda, sendo atribuído ao fato de nela viverem os acusados e estarem todos sob o "efeito da maldita". 
Entretanto, não só essas duas ruas do centro da cidade desfrutavam da atenção policial. A Baixa dos Sapateiros, região de intenso comércio e divertimento popular, com suas ligações com a cidade alta, era igualmente vigiada. Uma dessas ligações, a Ladeira de São Miguel, foi o palco da prisão de Caetano em 1958:

Quando se entregava a violenta luta corporal com um
outro desordeiro seu companheiro, foi detido ontem, pela
ronda policial noturna, Caetano Pereira de Jesus, malan-
dro contumaz de São Miguel, onde estabeleceu, junta-
mente com outros elementos de sua estirpe, o seu quartel
general.

Após a prisão, conduzido para a primeira delegacia de polícia, ali se constatou que o mesmo se encontrava sob o efeito da 'maldita'. Realmente, pouco depois esta suposição foi confirmada totalmente, porquanto, em verdade, Caetano havia tirado algumas baforadas no seu cigarrinho de maconha que, a despeito da 'severa e rigorosa' ação policial, continua a ser a companheira constante dos desordeiros em nosso 'bas-fond'. (SOB, 1958, p. 5)

Mais uma vez o tema central é maconha e comportamento violento. Surge ela aqui como a "companheira constante dos desordeiros", estratégia que visa transformar em "maconheiro" qualquer pessoa que por ventura viesse a se envolver numa briga. A Ladeira de São Miguel, acesso para o Pelourinho percorrido pelas classes trabalhadoras, se torna o "quartel general" da criminalidade, chefiado por um "maconheiro". Sem revelar os motivos que levaram os dois às vias de fato, o jornal reforça a ideia da violência como único resultado do uso de maconha ao explicar a "desordem" tendo isso como o elemento motivador.

E a maconha também era perseguida em outra ladeira extremamente popular e próxima a São Miguel, que também ligava a Baixa dos Sapateiros ao Pelourinho, a da Ordem Terceira de São Francisco: 
O investigador Celes, da Seção de Vigilância e Capturas, prendeu hoje pela manhã, em flagrante delito, o perigoso 'lanceiro', Hermes José de Oliveira, vulgo 'Pinta Preta', que estava sendo ‘caçado' pela polícia carioca.

'Pinta Preta' que possui tatuagem da cabeça aos pés, foi preso portando dois pacotes de maconha, na ladeira da Ordem Terceira, e conduzido imediatamente para o xadrez da Diretoria de Investigação. (CAÇADO, 1958, p. 5)

"Lanceiro" era o mesmo que "gatuno" na gíria policial, um dos sinônimos para "ladrão". (MACONHEIRO, 1958, p. 3; MOVIMENTO, 1958, p. 12) Deve-se indagar sobre quais motivos levaram a polícia a suspeitar de Hermes: o fato de ele estar na ladeira da Ordem Terceira? Suas tatuagens "da cabeça aos pés"?

Hermes, mais conhecido como "Pinta Preta", pelo visto, tinha certa mobilidade espacial, veio da capital carioca para Salvador, e esse característica não agradava o poder público nem a imprensa: é tacitamente reprovada e colocada sob suspeição, tornava-se um fugitivo, era "caçado pela polícia". Num lance a suspeita é ampliada para um espaço dentro do tecido urbano, não por acaso de intensa presença dos subalternos, para um comportamento e para um traço físico específico - as tatuagens. Características com certeza facilmente encontradas em muitos outros indivíduos como Hermes na Salvador da época.

Nesse mesmo ano de 1958 em que "Pinta Preta" foi preso, interessante matéria foi publicada nas páginas de A Tarde. A manchete trazia a conversa de um "maconheiro" com o repórter sobre sua prisão. Refletindo, então, sobre a peculiaridade dessa "linguagem", nos conta:

Uma particularidade interessante, no caso, é que a gíria vai surgindo de acordo com as situações, sendo expressões usadas geralmente por gatunos para contar um episódio qualquer das suas vidas criminosas. 
É o caso, por exemplo, de citarmos a explicação dada ao nosso repórter policial por um desses marginais, sobre a maneira por que se deu a sua prisão.

Disse-nos ele que 'chegando para sonar em sua maloca, cheio de malafa, não manjou que havia roupa na corda a despeito dos sinais da minestra, e o resultado é que entrou em cana. Foi uma mancada grossa, mesmo por que, para complicar tudo estava com as sulatas cheias da maldita...'.

Claro está que o repórter não compreendeu coisa alguma, solicitando a sua tradução que, simplesmente, é a seguinte:

'Chegando em casa para dormir, cheio de cachaça, não notou que havia alguém estranho, a despeito dos sinais de sua mulher, e o resultado foi a prisão. Foi uma grande facilidade, mesmo por que, para complicar a situação se encontrava com os bolsos cheios de maconha.' (CURIOSA, 1958, p. 7, grifo nosso)

Se não fosse pelo fato de que veio acompanhada de uma "tradução" daquele "vocabulário estranho", a matéria talvez não tivesse nada de especial.

Se a linguagem é o produto de um contexto social, construída a partir de um repertório de significados diretamente relacionado com a experiência histórica da classe que lhe emprega (BURKE; PORTER, 1997; HANKS, 2008), o que nos revela esse fato? $\mathrm{O}$ que se pode apreender, por meio dele, a despeito de ter sido um diálogo "real" ou "fictício"? Essas questões podem nos ajudar numa conclusão, que nada tem de definitiva, bem como, revela algo acerca da sociedade baiana na qual a maconha foi transformada num "problema social".

A "gíria" dos "maconheiros" surgia "de acordo com as situações", ou seja, esta linguagem estava sempre em movimento, sempre se recriando. Os termos criados eram usados pelos sujeitos para transmitir ao grupo sua experiência de uma 
forma que todos que compartilhassem o código pudessem compreender, atribuir sentido. Dessa forma, é uma linguagem que remete à uma experiência comum àquele grupo. Porém, dele não fazia parte o repórter, que "não compreendeu coisa alguma" e teve que recorrer a uma "tradução" para aquele "vocabulário estranho". Entretanto, mesmo de posse desses significados traduzidos, não atribuiria os mesmos sentidos, pois não compartilhava daquelas experiências.

Produzido pelos membros das elites letradas estaduais e destinado a uma minoria de alfabetizados, dentre os quais a quase totalidade não deveria pertencer àquele mundo dos subalternos, o jornal A Tarde foi insistente veiculador de matérias sobre os danos da maconha nesse periodo. Promoveu, sobretudo, uma campanha pedagógica que visava consolidar o processo proibicionista. A dificuldade dos leitores do periódico em compreender as expressões do "maconheiro" revela a existência da falha de comunicação e da distância que separava mundos, valores, hábitos e projetos de vida na Bahia.

As histórias de feirantes, camelôs, marinheiros, estudantes e gatunos em Salvador durante a década de 1950, acompanhadas até aqui, ajudaram a compreender por que reiteradamente se enfatizava que os usuários de maconha pertenciam "à última e mais baixa escala social". Esse postulado também pré-determinava uma série de características, as quais todos os usuários deveriam possuir. Contudo, foi percebido que não corresponde à multiplicidade de atores sociais que a consumiram. A criminalização da maconha na Bahia, além de servir como pretexto para o preconceito racial velado, sob o manto da salvação do "vício", serviu para fortalecer a discriminação de classe e se adequou muito bem aos planos de intervenção disciplinar no modo de vida dos subalternos. Mas será que foi tão bem assim? 